\title{
Operatör Doktor Ömer Vasfi Aybar ve Ankara'da Yayımladığı Türk Hekimi Dergisi
}

\section{Doctor Ömer Vasfi Aybar and Türk Hekimi, the Medical Journal He Published in Ankara}

\author{
Cem Hakan Başaran ${ }^{1}$ [, Nilüfer Poyraz Demirsoy ${ }^{2}$ (C)
}

'Arş. Gör. Dr., Osmangazi Üniversitesi, Tıp Fakültesi, Temel Tıp Bilimleri Bölümü, Tip Tarihi ve Etik Anabilim Dalı, Eskişehir, Türkiye ${ }^{2}$ Doç. Dr., Osmangazi Üniversitesi, Tip Fakültesi, Temel Tip Bilimleri Bölümü, Tip Tarihi ve Etik Anabilim Dalı, Eskişehir, Türkiye

ORCID: N.P.D. 0000-0002-2647-0807;

C.H.B. $0000-0002-4041-975 X$

Sorumlu yazar/Corresponding author: Nilüfer Poyraz Demirsoy,

Osmangazi Üniversitesi, Tıp Fakültesi, Temel Tıp Bilimleri Bölümü, Tıp Tarihi ve Etik Anabilim Dalı, Eskişehir, Türkiye

E-posta/E-mail: nilufer_p2@hotmail.com

Başvuru/Submitted: 22.07 .2019 Revizyon Talebi/Revision Requested: 16.08.2019

Son Revizyon/Last Revision Received:

27.10.2019

Kabul/Accepted: 04.11 .2019

Online Yayın/Published Online: 03.01 .2020

\section{Atıf/Citation:}

Poyraz Demirsoy, Nilüfer, ve Cem Hakan Başaran. "Operatör Doktor Ömer Vasfi Aybar ve Ankara'da Yayımladığı Türk Hekimi Dergisi." Osmanlı Bilimi Araștırmaları 21, 1 (2020): 71-100

https://doi.org/10.26650/oba.594925

\section{öz}

Eski harfli tıbbi süreli yayınlar içerisinde bugüne kadar çalışılmamış dergilerden birisi de Türk Hekimi dergisidir. Nadir bir dergi olan Türk Hekimi 1 Mart 1336 (1 Mart 1920) tarihinde yayın hayatına başlamıs ve kuvvetle muhtemel olarak aynı yıl içerisinde yayın hayatı son bulmuştur. Bu makalede, Türkiye'de sadece İstanbul Üniversitesi İstanbul Tıp Fakültesi Tıp Tarihi ve Etik Anabilim Dalı'nda iki sayısı bulunan Türk Hekimi dergisi incelenerek, bu iki sayının dizini çıkartılmıştır. Ayrıca, derginin sahibi olan Op. Dr. Ömer Vasfi Aybar'ın hayatı ve eserlerine dair bir biyo-bibliyografya denemesi yapılmıştır. Makalede, Türk Hekimi dergisi yayımlandığı dönemin koşulları ve Op. Dr. Ömer Vasfi Aybar'ın siyasi kimliği ve ilişkileriyle birlikte değerlendirilmeye çalışılmıştır. Makalenin sonunda yer alan ekler kısmında, Ömer Vasfi Bey'in Çanakkale Savaşı'ndaki cerrahi faaliyetlerini ve hatıralarını içeren bir yazısı, ulaşılabilen eserlerinin bir listesi, 1919 yılında Dr. Abdullah Cevdet'e yazdığı bir mektubu ve annesine uyguladığı operasyonu anlatan vaka sunumuna yer verilmiştir.

Anahtar sözcükler: Türk Hekimi, Ömer Vasfi Aybar, tıp dergileri, süreli yayınlar, tıp tarihi

\section{ABSTRACT}

Türk Hekimi, published with Arabic letters in Ankara, is one of the medical journals that have not been studied so far. Its publication began on March 1,1336 (1920) and ended, most probably, the same year. Only two issues are extant in Turkey, and these are kept at the Department of Medical History and Ethics, Istanbul Faculty of Medicine, Istanbul University. The present article, while introducing these two issues, will present a bio-bibliography of doctor Ömer Vasfi Aybar, the owner of the journal. The article will analyze the journal within the conditions of the period, taking into consideration Ömer Vasfi Aybar's political identity and relations. Its appendix includes an article by Dr. Aybar that narrates his surgical activities and memoirs at the Battle of Gallipoli; a list of his works; his letter of 1919 written to Dr. Abdullah Cevdet, and the case report of the surgery he performed on his mother.

Keywords: Türk Hekimi, Ömer Vasfi Aybar, medical journals, periodicals, history of medicine 


\section{Giriş}

Türk cerrahi tarihinde hatırlanması gereken isimlerden biri olan Ömer Vasfi Bey (1889-1969), ünlü cerrah Dr. Cemil Topuzlu Paşa'nın (1866-1958) yanında ihtisasını tamamlamış, çeşitli cephelerde çalışmış ve önemli hastanelerde başhekimlik yapmıştır. Osmanlı döneminde Ankara Gureba Hastanesi, Kurtuluş Savaşı sırasında Merkez Askeri Hastanesi’ne muadil olmak üzere Merkez Mülkiye Hastanesi olarak isimlendirilen Ankara Numune Hastanesi’nin kurucu başhekimliğini üstlenmiştir. Daha önceleri Vilâyet Hususi Muhasebe Encümen Azalarının idaresinde olan Numune Hastanesi, Cumhuriyet sonrasında Sıhhat ve İçtimai Muavenet Vekâleti'ne (Sağlık Bakanlığı'na) bağlanmıştır. Ömer Vasfi Bey, Sağlık Bakanı Dr. Refik Saydam'ın da desteğiyle hastanenin gelişmesi için önemli hizmetler vermiştir. ${ }^{1}$ Ömer Vasfi Bey'in uzun yıllar devam eden hekimlik ve başhekimlik hizmetlerinin yanı sıra tıp tarihi açısından önemli bir özelliği ise yaşadığı dönemde birçok tıp dergisinin yayımlanmasına öncülük etmiş olmasıdır. Cumhuriyet öncesinde ve sonrasında Anadolu'da yayımlanan bazı tıp dergilerinin imtiyaz sahipliğini ve başyazarlığını yapmanın yanı sıra çeşitli dergilerin de yayın kurullarında görev almıştır. Bunlardan bazıları şunlardır: Türk Hekimi [1920, Ankara, sahib-i imtiyaz], Hastahane [1924-1930?, Ankara, sahib-i imtiyaz], Fransızca-Türkçe yayınlanan Ankara Kliniği (La Clinique d'Ankara) [1930-1936, yayın heyeti üyeliği], Anadolu Kliniği [1933-1954, Konya, yayın heyeti üyeliği], Şirurji Mecmuası [1947-1954, yazı işleri müdürü]. ${ }^{2}$ Ömer Vasfi Bey'in Ankara'ya atandıktan sonra Ankara' daki faaliyetleri, Giresun Memleket Hastanesi’ne kısa süreli atanması, Paris'e izinli olarak bir yıl gitmesi ve bu süre zarfında başhekimlik pozisyonunu koruması hayatının daha az bilinen kısımlarını oluşturmaktadır. Ankara Hükûmeti tarafından kabul gören Ömer Vasfi Bey, her ne kadar Cumhuriyet döneminde siyasi bir mevki işgal etmese de önemli memuriyetlerde bulunmaya devam etmiştir. Ömer Vasfi Bey’in kaleme aldığı hal tercümesi hayatının bu dönemine (1919-1924) açıklık getirmekten uzaktır.

1 40. Yll Münasebetiyle Ankara Numune Hastanesi (Ankara: Ankara Numune Hastanesi, 1965), 7.

2 Ömer Vasfi Aybar, 1930-1936 yılları arasında Ankara Kliniği (La Clinique d'Ankara) dergisinin yayın heyeti üyeliği, 1947-1954 yılları arasında Şirurji Mecmuası'nın yazı işleri müdürlüğünü yapmıştır. Bu dergilerde aldığ 1 görevler, Ömer Vasfi Bey'in otobiyografisinden iktibas edilmiş olup makalemizin hazırlanış sürecinde orijinal kaynakları görme imkânı ne yazık ki bulunamamıştır. 


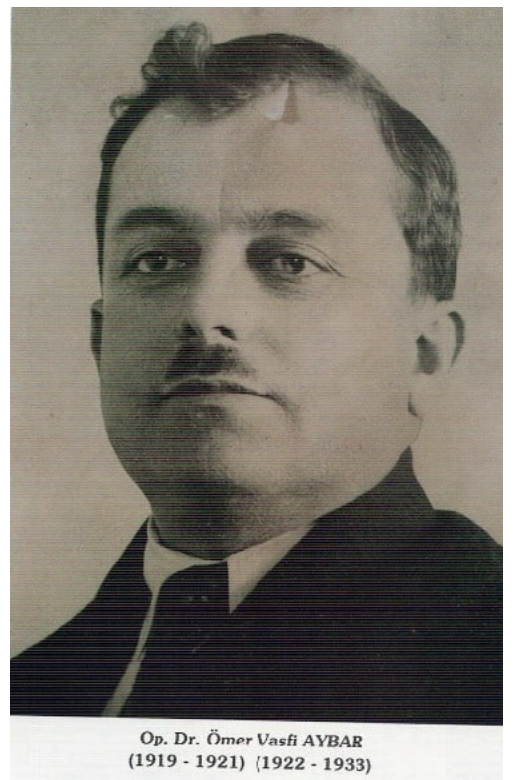

Resim 1. Op. Dr. Ömer Vasfi Aybar, 1919-1921 ve 1922-1933 y1llarında Ankara Numune Hastanesi'nin başhekimliğini yapmıştır

(https://numuneeah.saglik.gov.tr/TR,201718/dr-omer-vasfi-aybar-1919---1921-1922---1933.html).

\section{Kendi Kaleminden Op. Dr. Ömer Vasfi Aybar}

Ömer Vasfi Aybar'ın kendi kaleminden çıkmış bir biyografisi bulunmaktadır. Bu otobiyografi aşağıda verilmiştir: ${ }^{3}$

1889 yılında Trabzon'da doğdum. Lise tahsilimi Trabzon'da bitirdikten sonra tıbbiye mektebinin sivil kısmından 1912'de mezun oldum. Birinci hariciye müderrisi fâzıl ve âlim Cemil Topuzlu'nun kliniğinde asistanlık yaptıktan sonra ihtisas sertifikasını aldım. I. Cihan Harbine yüzbaşı rütbesi ile iştirak ederek Çanakkale Harbi'nde ilk toptan sonuna kadar vazife gördükten sonra iki buçuk sene de Diyarbakır'da II. Ordu Menzil Hastanesi operatörlüğünde ve baştabipliğinde bulundum. "Harp Madalyası", "Kı1lı̧̧1 Gümüş Liyakat”, “Gümüş İmtiyaz” madalyaları ile taltif olundum.

Mütarekede, terhisten sonra Ankara Gureba Hastanesi baştabip ve operatörlüğüne tayin edilerek Milli Mücadele'ye iştirak ettim. Bu arada dokuz ay kadar muvakkaten Giresun Hastanesi baştabipliğinde bulundum. ${ }^{4}$ Ankara'daki hayat-1 memuriyetim onsekiz seneyi

3 40. Yll Münasebetiyle Ankara Numune Hastanesi, 19-20.

4 Giresun'dan Ankara'ya Mart 1922'de tekrar atanmıştır. Atama haberi Anadolu Tıb Mecmuası'nda yayımlanmıştır:-“Mart 1338 [Mart 1922] Tebeddülât: Giresun Memleket Hastahanesi Sertabib ve Operatörü Ömer Vasfi Bey Ankara Gureba Hastahanesi Sertabib ve Operatörlüğüne atanmıştır.” (Anadolu Tıb Mecmuası 1, 5 (15 Nisan 1338 / 15 Nisan 1922): 32). Ömer Vasfi Bey otobiyografisinde Giresun'da 9 ay kadar geçici olarak çalıştığını belirttiği için Giresun Memleket Hastahanesi'ne Haziran-Temmuz 1921 tarihine denk düşen bir zamanda atanmış olmalıdır. Ömer Vasfi Bey, 1919-1921 ve 1922-Eylül 1933 tarihleri arasında Ankara 
bulmaktadır. Numune hastaneleri tesis olunduğu zaman Ankara Numune Hastanesi baştabip ve operatörlüğüne tayin edilerek bu hastanenin tesis ve tekâmülüne memur edildim. Şimdiki Ankara Numune Hastanesi tamamile baştabipliğim zamanında yaptırılmıştır. 1922'de bir sene mezunen Paris'te kalarak mesleki çalışmalarda bulundum. ${ }^{5}$

1927'de Hükûmet tarafından Ankara'da yaptırılacak büyük bir pavyon için resmen üç aylık Avrupa'da bir tetkik seyahatine memur edilerek Paris, Brüksel, Münih, Karlsruhe, Manheim'de etüdlerde bulundum. Ankara Numune Hastanesi'nin büyük merkez pavyonu bu etütlerin mahsulüdür. Sonraları mesleki tetkikler için tekrar Paris ve Almanya'ya gittim. 1934'de Moskova'da toplanan Beynelmilel Romatizma Kongresine merhum Akil Muhtar ve Zeki Nasır ile birlikte Kızılay delegesi olarak iştirak ettim. 1935'de Devlet delegesi sıfatile Kahire'deki Beynelmilel Cerrahi Cemiyeti kongresine iştirak ettim. ${ }^{6}$

1937 yılından itibaren Şişli Çocuk Hastanesi baştabip ve operatörlügüünde ${ }^{7}$ munzam vazife olarak yeniden tesis olunan Hastabakıcı, Hemşire ve Laborant Okulu müdürlüğünü ifa ederken bir derece terfi ve takdirname ile emekliye ayrıldım (19.10.1949).

Numune Hastanesi'nde başhekimlik yapmıştır. Eylül 1933 ile 19 Nisan 1937 tarihleri arasında ise aynı hastanenin I. Hariciye Kliniği'nde çalışmıştır (40. Yll Münasebetiyle, 175). Ömer Vasfi Bey, Giresun Memleket Hastahanesi'nde iken yerine Dr. Sadi Konuk Başhekim olarak atanmıştır (Cumhuriyetimizin 75. Yılında Ankara Numune Eğitim ve Araştırma Hastanesi (Ankara: Ankara Numune Eğitim ve Araştırma Hastanesi, 1998), 17-18). Bu eserde Sadi Konuk’un başhekimliği ile ilgili herhangi bir kaynak gösterilmemiştir. Dr. Sadi Konuk'un başhekimliği döneminde Ankara Gureba Hastahanesi başhekimi imzasıyla yayınladığı makaleler için bkz. Ankara Gureba Hastahanesi Sertabib ve Operatörü Dr. Sadi Rasim [Sadi Konuk] ve Dr. Ragıb Naili, "Cürûh-1 harbiyeden mütevellid kırıklar," Anadolu Tıb Mecmuası 1, 3 (15 Şubat 1338 /15 Şubat 1922): 7-9; Ankara Gureba Hastahanesi Sertabib ve Operatörü Dr. Sadi Rasim [Sadi Konuk], "Tâlî hurac-1 muhit-i kilye tevlid eden bir hurac-1 pankreas vakası," Anadolu Tıb Mecmuası 1, 4 (15 Mart 1338 / 15 Mart 1922): 21-24.

5 Ömer Vasfi Bey Paris’te Eylül / Ekim 1922 ile Eylül / Ekim 1923 tarihleri arasında bulunmuş olmalıdır. Paris'e gitmeden evvel yayınladığı son makalesi ve döndükten sonra yayınladığı ilk makalesi için bkz. Ankara Mülkiye Hastahanesi Sertabibi Op. Dr. Ömer Vasfi, "Müstacel Cerrahi Mebahisinden: İleuslar [2]," Anadolu Tıb Mecmuası 1, 9 (15 Eylül 1338 / 15 Eylül 1922): 8-12; Ankara Mülkiye Hastahanesi Sertabibi Op. Dr. Ömer Vasfi, “Anevrizmaların Cerrahi Tedavisine Dair,” Askeri Tıb Mecmuası 52, 10-11-12 (Teşrinievvel-TeşrinisaniKanunuevvel 1339 / Ekim - Kasım - Aralık 1923): 331-334. Ömer Vasfi Bey’in Paris’te bulunduğu sirada Ankara Mülkiye [Gureba] Hastahanesi’ne Bezmialem Valide Sultan ve Hamidiye Etfal Hastahaneleri üroloğu olan Dr. Behçet Sabit [Erduran] vekâleten atanmıştır. Behçet Sabit Bey, Ankara’ya Atatürk'ün hastalığını [pyelonefrit] tedavi etmek için davet edilmiştir. Bedi N. Şehsuvaroğlu, Atatürk'ün Sağlık Hayatı (İstanbul: Hür Yayınları, 1981), 7-8. Behçet Sabit'in başhekimliğe vekâlet ettiği dönemde başhekim vekili imzasıyla yayımladığı makaleler için bkz. Ankara Sıhhiye Müdür ve Mülkiye Hastahanesi Sertabib ve Operatör Vekili Ürolog Dr. Behçet Sabit, "Mehd-i istiklalden (İstiklalin beşiği Ankara'dan) İstanbul Seririyatı'na bir hatıra-yı hürmet, Cerrahi-i Turuk-1 Bevliye Hastalıklarında Mesanebinin Ehemmiyeti ve Tarihçesi," İstanbul Seririyatı 3, 9 (Kanunusani 1339 / Ocak 1923): 262-263; Ürolog-Operatör Dr. Behçet Sabit, "Ankara Vilâyet Hastahanesi cerrahi mesaisinden tesakkub-1 rahim ile müterafik cebri ve cerri fitk-1 miai-i muhtenik," İstanbul Seririyatı 3, 13 (Mayıs 1339 / Mayıs 1923): 329-330. Behçet Sabit Bey ile Ömer Vasfi Bey Çanakkale Cephesi'nde birlikte çalışan yakın arkadaşlardı. Bu iki doktorun cephedeki hatıraları için bkz. Behçet Sabit Erduran, Cephedeki Bir Doktorun Gözünden: 1915 Baharında Çanakkale, yay. haz. Tamay Açıkel (İstanbul: Türkiye İş Bankası Kültür Yayınlar1, 2015), 92, 100, 122, 130-31, 140.

6 Kongreye Türkiye'den Dr. Tevfik Remzi Kazancıgil, Dr. Kazım İsmail Gürkan, Dr. Ömer Vasfi Aybar ve Dr. Emin Erkul Seyitoğlu katılmıştır. Kongre heyetinin kongre balosunda çekilmiş fotoğrafi ve Misır'da Mehmet Akif Ersoy’a yaptıkları ziyareti aktaran bir yazı için bkz. Aykut Kazancıgil, "Mısır'da Âşinâ Bir Çehre," Derin Tarih, 81 (Aralık 2018): 62-63.

7 Ömer Vasfi Bey, Şişli Çocuk Hastanesi baştabip ve operatörlüğüne 7-30 Mayıs 1937 tarihleri arasındaki atamalarda kendi talebiyle atanmıştır. "Muamelesi: Talebi veçhile Çocuk Hastanesi Baştabip ve Operatörlügüne tayini," Sihhiye Mecmuası 13, 86 (Haziran 1937): 155. 
Türk Cerrahisi Cemiyeti'nin İkinci Kongresinde "Narkoz" raportörlügünü yaparak bir cilt halinde son malumat ve keşiflerle birlikte gerek şahsi ve gerek memleketteki meslektaşlarımın görgüleri istatistiklerle tevsik edilmiş bir eser neşr olunmuştur. Senelerce Türk Cerrahi Cemiyeti'nin ikinci reisliğini yaparak (Şirürji) mecmuasının yazı işlerini idare ettim. Bir devre Türkiye Hastane Mütehassısları Derneği’nin reisliğinde de bulundum.”

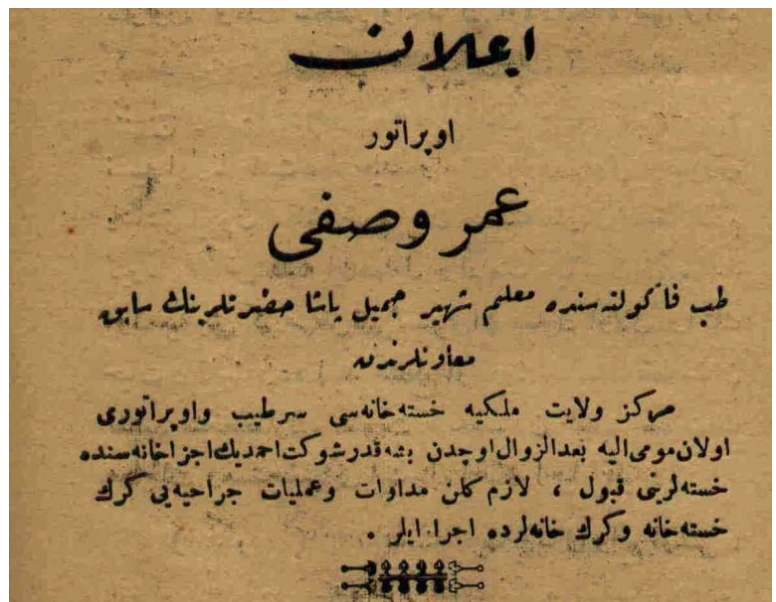

Resim 2. Ömer Vasfi Bey'in Mefkûre mecmuasına verdiği bir ilan:

“Operatör Ömer Vasfi, Tıb Fakültesinde Muallim-i şehir Cemil Paşa [Topuzlu] Hazretlerinin sabık muavinlerinden. Merkez Vilâyet Mülkiye Hastahanesi Sertabib ve Operatörü olan mumaileyh badezzeval üçden beşe kadar Şevket Ahmet Bey Eczahanesi'nde hastalarını kabul, lâzım gelen müdâvat ve ameliyat-1 cerrahiyeyi gerek hastahane ve gerek hanelerde icra eder

(Mefkûre sayı 1 (30 Mart 1335 [1919]): 8).

\section{Ömer Vasfi Bey’in Kurtuluş Savaşı ve Cumhuriyetin Kuruluş Dönemi (1919-1924) Yılları}

Ömer Vasfi Bey, Mütareke Döneminde İstanbul Hükûmeti tarafından Diyarbakır II. Ordu Menzil Hastanesi'nden Ankara Gureba Hastanesi'ne başhekim olarak atanmıştır. ${ }^{8}$ Ankara'da bulunan hekimlerin bir kısmı, dönemin Ankara Vilayeti Sihhiye Müdürü olan Dr. Muhittin Celal Duru'nun' sahibi ve müdürü olduğu "Fenni, edebi, ilmi haftalık risale" olarak nitelendirilen ve Mefkûre başlığıyla neşredilen derginin etrafında birleşmişler, ${ }^{10}$ siyasi ve

8 Atamanın tam tarihi dönemin dergileri taranmasına rağmen ne yazık ki tespit edilememiştir. Ancak Ankara'da Dr. Muhittin Celal Duru tarafından yayımlanan Mefkûre mecmuası incelendiğinde Mart 1919'da görevi başındadır. Mefkûre 1, 8 (30 Mart 1335 / 1919): 8. O dönemde, hastahanenin diğer kadrolu hekimi Bakteriyolog Dr. [Evliyazade] Adil Bey'dir.

9 Ali Birinci, “Türk Yurdu Kalemleri: Dr. Muhittin Celal Duru,” Türk Yurdu sayı 352 (Aralık 2016): 65.

10 Mefkûre mecmuasının ulaşılabilen en büyük koleksiyonu Ankara Milli Kütüphane'de bulunmaktadır. Ulaşılabilen sayıları 1-7, 9-10, 12 numaralı sayılarıdır. Mefkûre mecmuasında yazılarına tesadüf edilen hekimler ve yazarlar: Dr. Muhittin Celal Duru, Dr. Ömer Vasfi Aybar, Dr. [Evliyazade] Adil, Dr. Osman Yaşar, Halil Nihat Boztepe, Cevad Hakkı Tarım, Ahmed Sahib, Osman Cevdet, S1dkı Hamid, ve Mehmed Muhsin Beylerdir. 
sosyal fikirlerini açıkça yayma imkânı bulabilmişlerdir. Ömer Vasfi Bey, bu dergide 1slahatçı fikirlerini içeren yazılar neşretmiştir. Yazılarında savaş karşıtı bir tutum benimsemiş, Türk milletinin artık askeri anlamda üstünlüğünün sona erdiğini, ilim sahasında ilerlemeye ihtiyacı olduğunu, hükûmetin bir an evvel insan gücünü ön plana alarak koruyucu sağlık hizmetlerini geliştirmesi ve sıhhiye işlerinin Dâhiliye Nezareti'nden ayrılıp Sıhhiye Nezareti adı altında yönetilmesi gerektiğini savunmuştur. Yine Mefkûre mecmuası aracılığıyla 27 Mart 1919 tarihinde Hürriyet ve İtilaf Fırkası tarafından azledilen Dr. Adnan Adıvar'ın yerine İngilizlerin baskısıyla göreve getirilen dönemin Sıhhiye Müdür-i Umumisi Dr. Abdullah Cevdet [Karlıdağ] Bey'e ${ }^{11}$ desteğini açık bir mektupla ilan etmiştir. [Ek-3]

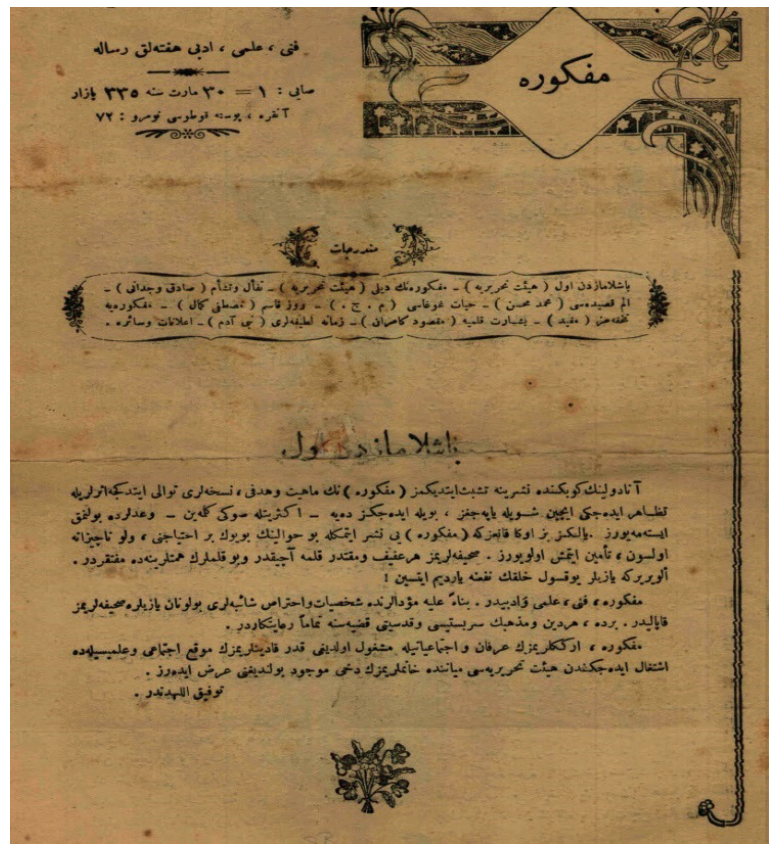

Resim 3. Dr. Muhittin Celal Duru'nun sahibi olduğu ve Op. Dr. Ömer Vasfi Bey’in siyasi ve sosyal içerikli makaleler neşrettiği Mefkûre mecmuasının 30 Mart 1919 tarihli ilk sayısının kapağ 1 (Ankara, Milli Kütüphane).

Ankara'nın 1919'da karışık olan siyasal havasında'2 manda karşıtı milli hareketlerin

11 Nuran Yıldırım, "Hekim Kimliği ile Abdülhak Adnan Adıvar ve Tıp Tarihi ve Deontoloji Müderrisliği," Osmanll Bilimi Araştırmaları 7, 2 (2006): 68.

12 Ankara'nın 1919 yılında içinde bulunduğu siyasal durum şöyle anlatılır: "1919 yılında Ankara'da işgal kuvvetlerine bağlı İngiliz ve Fransız askerler bulunmaktaydı. İngilizler, İstasyon civarında, Fransızlar ise o dönemlerde İttihat Terakki Merkezi olarak yapılan binada karargâh kurmuşlardı. İleride 1. Millet Meclisi olarak istiklâl ve bağımsızlığımızın karargâhı olacak bu bina, acıdır ki, Fransız askerlerine karargâhlık yapıyordu ve üstünde Fransız bayrağı asılıydı. Diğer yandan, tüm ülkede olduğu gibi Ankara'da da hem hükümet merkezi İstanbul'un hem de İzmir'in ve Anadolu'nun diğer bölgelerinin işgali büyük bir üzüntü yaratmıştı. İşgale karşı Ankaralılar yoğun bir tepki içerisindeydi. Damat Ferit Paşa hükümetinin atadığı Ankara Valisi Muhittin Paşa ise İstanbul'dan aldığı emirlerle Ankara'daki milli hareketleri söndürmeye çalışıyordu... Üstelik 
yanında İstanbul Hükûmeti’nin yöneticiler aracılığıyla sivil ve askeri memurlar üzerinde tahakkümü sürmekteydi. Dönemin Ankara Valisi Muhittin Paşa, Ankara içinde İngiliz Muhipleri Cemiyeti’nin kuvvetlenmesini sağlamak için büyük çabalar harcamakta, yeni filizlenmekte olan milli hareketi bastırmaya yönelik faaliyetlerine devam etmekteydi. Merkezi Ankara'da bulunan bir kuvâ-yı milliye teşkilatının varlığını haber alan Muhittin Paşa, bu harekete katılanları tutuklamak ve hareketi bastırmak üzere direktif almak için İstanbul'a gitmiş, 9 Ağustos'ta Ankara'ya döndükten sonra, "Padişahın ve hükûmetin İngiliz mandasını kabul ettiğini” söyleyerek memurları İngiliz Muhipleri Cemiyeti’ne girmeye zorlamıştır. ${ }^{13}$

Ömer Vasfi Bey, Ankara Valisi Muhittin Paşa'nın isteğine uyarak (veya baskılarına boyun eğmek zorunda kalarak) İngiliz Muhipleri Cemiyeti'nin Ankara şubesinin kurucuları arasında bulunmuş, böylece Padişah taraftarlığını beyan etmiştir. ${ }^{14}$ İngiliz Muhipleri Cemiyeti'nin Ankara'da kuruluşundan kısa süre sonra, her türlü propaganda ve baskıya rağmen başarılı olamayacağını anlayan Muhittin Paşa Çorum'a gitmiş, Ankara’ya dönmek üzere yola çıkmışken kuvâ-yı milliyeciler tarafından 18 Eylül'de tutuklanarak Sivas'a götürülmüştür. ${ }^{15}$ Mustafa Kemal Paşa'nın 27 Aralık 1919'da Ankara'ya gelişinin ardından Milli Mücadele'nin merkezi Ankara olmuş ve 23 Nisan 1920’de Türkiye Büyük Millet Meclisi açılmıştır.

Ömer Vasfi Bey'in Türk Hekimi dergisini neşrettiği dönem tam da bu ara döneme tesadüf etmektedir. Türk Hekimi dergisinin ilk sayısı (1 Mart 1920), Türkiye Büyük Millet Meclisi'nin açılışından (23 Nisan 1920) yaklaşık iki ay önce yayımlanmıştır. Derginin ikinci (son) sayısı ise Meclis'in açıldığı günlerde, 26 Nisan 1920'de, yayımlanmıştır. Ömer Vasfi Bey’in, çıkardığı dergiye Türk Hekimi adını vererek Ankara Hükûmeti'ne ve ulusal programına bağlılığını ilan etmek istediği düşünülebilir. Nitekim derginin birinci sayısında yayımlanan "Türk Hekimi’nin Maksad ve Mesleği” başlıklı önsöz dikkatle incelendiğinde, bir tür savunma metni özelliği taşıdığı görülmektedir.

Ömer Vasfi Bey, Ankara Hükûmeti'nin ilk Sihhat ve İçtimai Muavenet Vekili Dr. Adnan Adıvar'ın vekilliği (3 Mayıs 1920 - 2 Mart 1921) döneminde ${ }^{16}$ Gureba Hastanesi'ndeki başhekimlik görevini korumuştur. Dr. Adıvar'ın yerine atanan Dr. Refik Saydam'ın vekilliği

İngilizlerin Ankara'da İngiliz Muhipleri Cemiyeti’ni kurma çalışmaları İstanbul hükümeti ve vali tarafindan destekleni[yordu]." Metin Özarslan, "İşbirlikçiliğe isyan telgrafı çeken Ankara: "Senin gibi sadrazamı tanımayı,, Cumhuriyet, 29 Ekim 2012, s. 12.

13 Selahattin Tansel, Mondros 'tan Mudanya'ya Kadar, c.2 (Ankara: Başbakanlık Basımevi, 1973), 119-120.

14 İngiliz Muhipleri Cemiyeti'nin Ankara şubesinin kurucuları arasında 25 Ağustos 1335 / 1919 tarihli Mefkûre Gazetesi'ne göre; Dr. Ömer Vasfi (Reis), Dr. Muhittin Celâl (Kâtib-i umumi), tüccardan Arapzade Ziya, Dr. [Evliyazade] Adil, Dr. Osman Yaşar, matbaa müdürü Nihat Beyler aza olarak gözükmektedir. Tarık Zafer Tunaya, Türkiye'de Siyasal Partiler, c. 2, Mütareke Dönemi (İstanbul: Hürriyet Vakfi, 1986), 477. Mefkûre mecmuasının sahib-i imtiyazı olan Dr. Muhittin Celal Duru ve yayın heyetinde bulunan Dr. Ömer Vasfi ve Dr. [Evliyazade] Adil Bey daha sonra Türk Hekimi dergisini birlikte çıkarmışlardır.

15 Tansel, Mondros 'tan Mudanya'ya Kadar, 120.

16 Yıldırım, "Hekim Kimliği ile Abdülhak Adnan," 69-71. 
(ilk vekilliği 10 Mart 1921 - 24 Aralık 1921) döneminde ise Giresun Memleket Hastanesi’ne başhekim olarak tayin edilmiştir. Şüphesiz bu dönemde, gerek Adıvar gerekse Saydam, idari kadroların tayin ve atamalarında kişisel olarak kendilerine veya siyasi anlayışlarına yakınlık ve uzaklığı göz önünde bulundurmuş olmalıdır. ${ }^{17}$ Ömer Vasfi Bey’in Ankara Gureba Hastanesi başhekimliğinden neden uzaklaştırıldığı veya bu tayini bizzat kendisinin mi talep ettiği konusunda kesin bir hüküm vermek zor görünmektedir. Bununla birlikte, Ömer Vasfi Bey'in Ankara Gureba Hastanesi'nden ayrılıp Giresun Memleket Hastanesi'ne atanmasının bir nedeni, o dönemde pek çok hekimin yaptığı gibi yurtdışına gitmek için taşrada çalışarak para biriktirmek isteği olabilir. Öte yandan, İngiliz Muhipleri Cemiyeti bağlantısı dolayısıyla Ankara'nın siyasi ortamından kendi isteğiyle uzaklaşmayı tercih etmiş olabilir. Kesin olan ise, Ömer Vasfi Bey'in 9 ay müddetle Giresun'da çalıştıktan sonra tekrar Ankara'da görevlendirilmiş olmasıdır. Ömer Vasfi Bey’in bu süre içerisinde yeni Sıhhat ve İçtimai Muavenet Vekili Dr. Rıza Nur’un güvenini ve desteğini kazandığı anlaşılmaktadır.

Ömer Vasfi Bey, Mart 1922'de Ankara Gureba Hastanesi’ne yeniden başhekim olarak tayin edildikten sonra, aynı yıl içinde "bir sene mezunen" (izinli olarak) Paris'te mesleki çalışmalarda bulunmuştur. Anadolu'da Kurtuluş Savaşı'nın devam ettiği bu dönemde, Sıhhat ve İçtimai Muavenet Vekâleti, Dr. Ömer Vasfi Bey’in yurtdışındaki çalışmalarını maddi olarak destekleyebilecek durumda değildir. Ömer Vasfi Bey (maaşlı veya ücretsiz) izinli sayılmış ve yurtdışında iken başhekimlik görevini korumuştur. Bu süre zarfinda yerine Dr. Behçet Sabit Erduran vekâlet etmiştir. Ömer Vasfi Bey, hatıralarında, Çankaya’ya sık sık çağırılan Ankara'nın yegâne hekimi olduğunu belirtmekle birlikte, Paris'e gitmeden evvel de siyasal olarak tehlikede olduğunu yazmaktadır. ${ }^{18}$

17 Ömer Vasfi Bey’in yakın arkadaşı olduğu anlaşılan Dr. Muhittin Celal Duru, bu dönemde Sihhiye ve İçtimai Vekâleti Muhacirin Şube Müdürlüğü’ne atanmış hatta bu vazifede iken bir aralık İstanbul Vilayeti Sihhiye Müdürlüğü vazifesine tayin edilmiştir. Muhacirin Şube Müdürlüğü vazifesini 1 Temmuz 1921-4 Kasım 1923 tarihleri arasında yürütmüştür. Birinci, "Muhittin Celal," 65.

18 Ömer Vasfi Bey’in şu hatırası dikkat çekicidir: "Üçüncü hatıram mühimdir. Çünkü şahsımın, siyaset alanının ve Parti entrikalarının torpillerine çarpmak tehlikesi vardı: Bu hadiseyi ilk defa açıklıyorum. Hadise Yunanlıları denize döken Büyük Taarruz’a takaddüm eden günlerde [Ağustos-Eylül 1922] vaki olmuştur. Hastanemizin arkasındaki lise binasında Erkânı Harbiye ve Milli Müdafaa Vekâleti yerleşmişlerdi. Ankara boşaltıldığından biz hekimler bekâr olarak hastanede kalıyorduk. Ekseri geceler Erkânıharp zabit arkadaşlarla buluşarak sohbet ederdik. Halen berhayat olan ve isimlerini kayda lüzum görmediğim zabit arkadaşlar bize cephe ve harekât hakkında malûmat vererek "Afyon cephesinin kilidi bulunan (Döğer) istasyonu eğer bir hamlede geri alınırsa, Afyon yolu açılarak askeri harekât lehimize döner" diyorlardı. Bizler de bu telkinin tesiri altında idik. Nihayet taarruz başladı ve ilk ağızda (Döğer) istasyonu istirdat edildi. Aşırı derece sevindik. O gece 5-6 teneke gazyağı tedarik ederek kül ile yoğurduktan sonra hastane çevresinde bunları yakıp "icra-yı şâdumanî" ettik. Diğer resmi dairelerde ve şehirde hiçbir sevinç tezahürü yoktu. Yalnız gece yarısına doğru Merkez Kumandanı merhum Fuat Bulca'nın tertibi ile onbeş yirmi asker fener alayı yaptılar. Biz ertesi gün hayırlı haberi tafsilatı ile öğrenmeye çalışırken şimdiye kadar hastanemizin semtine uğramayan Vali Abdülkadir Bey kalın bastonuna dayanarak hastaneye geldi, bahçede oturup beni karşısına aldı. Yanımıza başka kimseyi istemedi. Valinin esasen sempatik olmaktan uzak bulunan siması bir hiddet kisvesine bürünmüş ve korkunç bir hal almıştı. Ben bu vaziyetten hayrette kaldım. Vali birden bastonunu yere vurarak gürler gibi bir sesle "Baştabip bey, dün geceki şenliğin yapılmasını kim söyledi, masrafını sana kim verdi, nereden ve ne için verildi?” demesin mi? Derhal 
Dr. Ömer Vasfi Bey, otobiyografisinde, "Mütarekede, terhisten sonra Ankara Gureba Hastanesi baştabip ve operatörlüğüne tayin edilerek Millî Mücadele'ye iştirak ettim” demektedir. Ancak, Milli Mücadele sırasında - Haziran/Temmuz 1921 ile Mart 1922 tarihleri dışında (Giresun Memleket Hastanesi başhekimliği dönemi) - Ankara'da görev yapmıştır. Sakarya Muharebeleri sırasında Ankara'da değildir; saydığı madalyalar arasında İstiklal Madalyası yoktur.

Ömer Vasfi Bey'in hayatında bu yıllarına ilişkin ilginç bir gelişme ise Nisan 1921'de (Giresun Memleket Hastanesi'ne atanmadan evvel) II. İnönü Savaşı'ndan sonra Mustafa Kemal Atatürk'ün sol yanağında çıkan büyük bir çıbanı Op. Dr. Emin Erkul Seyitoğlu ve Kozan Mebusu Dr. Fikret Onuralp ile birlikte tedavi etmesidir. ${ }^{19}$

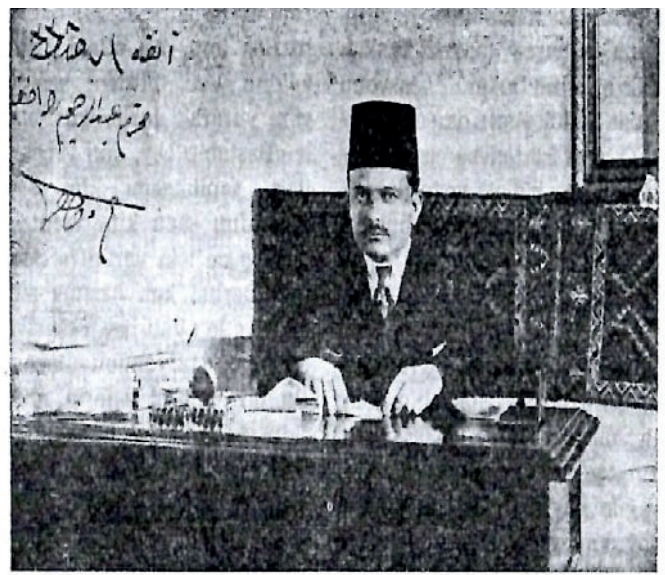

1922 de Hastahane Baștabib! Ömer Vasfi Bey

Resim 4. Ömer Vasfi Bey 1922'de hastane başhekimi iken (Paris'e gitmeden bir süre önce). [Fotoğraf yazısı: Ankara, 7 Haziran 1338 (1922), Muhterem Abdürrahim Beyefendiye, Ö. Vasfi] (40. Yll Münasebetiyle Ankara Numune Hastanesi, 13).

kan başıma sıçradı. Asabiyetle "Vali Bey, askerlerimiz (Döğer) istasyonunu işgal etti. Bu bir umumi zaferin müjdecisidir. Sevindik ve bu şenliği yaptık. Paraya gelince, bendeniz kesemden onbeş yirmi lirayı düşünmeden sarf edebilecek vaziyetteyim. Ne bir yerden para aldım ve ne hastaneyi masrafa soktum, buyurun tahkik edin. Efendim (Döğer)'ın zaptı müjdesi bu meserret nümayişine değmez mi?" bana cevaben "Sizi teşvik ettiler, bu işi yaptınız. Bakın biz Hükûmet olarak böyle bir şeye lüzum görmedik. Meydanda bir şey yok. Haydi, işinize bakın, Hükûmetin haberi olmadan böyle şeylere teşebbüs etmeyin ve başkalarının telkinine tabi olmayın." diyerek ve selam vermeden çekilip gitti. Fakat bizi bir düşünce aldı. Vali şu masumane hareketimizden niçin bu kadar hiddetleniyor? Neden sonra mesele anlaşıldı, bu adam meğerse Atatürk’ün can düşmanı imiş. Nitekim İzmir suikastının korkunç mürettiplerinden olmak ittihamı ile Ankara'da salben idam edilmiştir. Parti intikamı ve siyaset düşüncelerile Ata'nın prestijini yıkmaya çalışan, Ata şerefine yakılan beş on meşalenin aydınlığına tahammül edemeyen bu kara ve hain hisli adam nihayet ceza-i sezâsını bulmuştu. Şurasını da kaydedeyim ki Çankaya Köşküne sık sık çağırılan, Ankara'nın yegâne hekimi idim. Vali para ve telkini oradan aldığıma haksız olarak ihtimal vermiş olsa gerek. 40. Yıl Münasebetiyle Ankara Numune Hastanesi, 13-15. Orijinal metinde "Döğer İstasyonu", "Doker İstasyonu” olarak yanlış verilmiştir.

19 Şehsuvaroğlu, Atatürk'ün Sağllk Hayatı, 10. 
Başarılı bir cerrah olduğu anlaşılan Ömer Vasfi Bey, Paris’ten döndükten sonra başhekimlik kadrosuna geri dönmüş, Cumhuriyet sonrasında da Sıhhat ve İçtimai Muavenet Vekili Dr. Refik Saydam'ın açık desteğini görmüştür. Refik Bey’in verdiği maddi ve manevi destek, Ekim 1924'te Ömer Vasfi Bey tarafından çıkarılmaya başlanan Hastahane mecmuasından anlaşılmaktadır. ${ }^{20}$ Hatta Hastahane mecmuası yayın hayatına başlamadan bir süre önce, Mart 1924'de Ankara'da Ömer Vasfi Bey'in kurucularından birisi olduğu bir tıp cemiyetinin tesis edildiği haberini olarak yayınlansa da bu tıbbi cemiyete dair bilgi elde edilememiştir. ${ }^{21}$

\section{Numune Hastanesi, Hastahane mecmuası ve Sonrası}

\section{Mayıs 1924’te Numune Hastanesi'ne dönüşen Mülkiye [Gureba] Hastanesi şüphesiz} Cumhuriyet'in yarattığı sosyal gelişmenin bir örneği olarak görülmekte ve hükûmet hastane için önemli yatırımlar yapmaktaydı. Yeni hastanenin tüm kadrosu tasfiye edilmesine rağmen Ömer Vasfi Bey başhekim olarak makamını korumuştu. ${ }^{22}$ Cumhuriyet' in ilk örnek hastanesinin kurucu başhekimi olan Ömer Vasfi Bey’e Bakan Refik Saydam Bey’in açık desteğiyle bir de Cumhuriyet'in ilk tıp dergisini çıkarma vazifesi verilmiş ve Refik Bey'in delaletiyle bakanlık tarafından da maddi destek sağlanmıştı. Hastahane mecmuasının gerek ilk sayısındaki “Maksad ve Meslek” başlıklı giriş yazısında, gerekse diğer sayılarda bu durum belirtilmiştir:

....Şunu da arz edelim ki gazetemizin herçi-bad-abad [her ne olursa olsun] bir sene müddetle intişarı maddeten temin olunmuştur. Maa-hazâ etibba arkadaşların ufak bir alâkası Cumhuriyetimizin bu ilk ceride-i tıbbiyesini ebediyyen yaşatmağa kâfidir. ${ }^{23}$

20 Cumhuriyet öncesinde ve sonrasında birçok ünlü hekim Ankara Hükûmeti tarafından geçmişteki siyasal ilişkileri nedeniyle destek/kabul görmemiştir. Bunlara örnek olarak Malta sürgününden döndükten sonra Ankara Gureba Hastanesi'nde fahri olarak çalışan İttihat ve Terakki Cemiyeti ile ilişkisi nedeniyle Ankara Hükûmeti tarafından kendisine ilgi gösterilmeyen ve görev önerilmeyen Dr. Esat (Işı1k) Paşa verilebilir. Diğer bir örnek, gazetelere yansıyan İngiliz Muhipleri Cemiyeti Fahri Reisliği nedeniyle Heyet-i Mahsusa [Cemil Topuzlu'yu sorgulayan komisyonun reisi talebesi Op. Dr. Emin Erkul Seyitoğlu'dur] tarafından dosyası incelenen ve bir süre medeni haklarından mahrum bırakılan Op. Dr. Cemil (Topuzlu) Paşa'dır. Şeref Etker, “Ophtalmoscope Essad," Osmanlı Bilimi Araştırmaları 9,1 (2008): 157; Cemil Topuzlu, İstibdat-Meşrutiyet-Cumhuriyet Devirlerinde, 80 Yıllık Hatıralarım, 6. bs., yay. haz. Hüsrev Hatemi ve Aykut Kazancıgil (İstanbul: İşaret, 2017), 234-236.

21 'Bu hafta Ankara'da da bir cemiyet-i tıbbiye tesis etmiştir. Operatör Nüzhet [Çevik] Bey’in Reis ve Operatör Ömer Vasfi [Aybar] Bey'in Kâtib-i umumi olduğu bu yeni cemiyeti tebrik ve muvaffakiyetler temenni eyleriz," Ístanbul Seririyatı 5, 11 (Mart 1340 / Mart 1924): 117. Op. Dr. Nüzhet Çevik 1923-24'de Ankara Cebeci Hastanesi Hariciye Şefliğinde görevli iken 1924'de Balıkesir Hastahanesi baştabip ve operatörlüğüne tayin edilmiştir. Fethi Erden, Türk Hekimleri Biyografisi (İstanbul: Çituri Biraderler Basımevi, 1948), 67. Adı geçen cemiyetin isminin ne olduğu ve faaliyete geçip geçmediğine dair ne yazık ki bir bilgiye ulaşılamamıştır.

22 Hastanenin gelişimi ile ilgili ayrıntılı bilgi için bkz. Sadet Altay, Atatürk Döneminde Numune Hastanelerine Dönüştürülen Osmanlı Hastaneleri (1924-1938) (Ankara: Atatürk Araştırma Merkezi, 2019), 57-115. Refik Saydam Bey’in mecliste verdiği malumata göre o dönemde hastane takriben 50 yataklı, vesaitten mahrum, 2 doktorlu, noksan kadrolu ve pek noksan malzemeli idi. Dolayısıyla Ömer Vasfi Bey dışında hastanede bir kişi çalışmaktaydı [hastaneye kadrolu hekimler dışında fahri hekimler ve konsültan hekimlerde gelmekteydi.] Sihhiye Mecmuası 5, 22 (Kanunusani 1929): 132. Bu vesile ile bazı kaynakları bizimle paylaşan Dr. Sadet Altay'a nezaketi, ilgisi ve yardımlarından dolayı teşekkür ediyoruz.

23 Hastahane 1, 1(Teşrinievvel 1340): 1; Sihhiye ve Muavenet İçtimaiye Vekâleti'ne ve Refik Saydam Bey’e maddi ve manevi destekleri için yayınlanan diğer teşekkür yazıları için bkz. "Vekâlet-i celileye arz-1 şükran," Hastahane 1, 5 (Şubat 1341): 1; “Arz-1 şükran ve takdim-i tebrikat,” Hastahane 1, 12 (Eylül 1341): arka kapak; 
Hatta mecmuanın abonelik bedeli ve nüsha bedeli belirlenmiş olsa da, ilk sene, bir kısım okuyucuya -muhtemelen vekâletin tasarruf ettiği kişi ve kurumlara- ücretsiz dağıtılmıştır. ${ }^{24}$ Mecmua ikinci yılını tamamlarken Refik Bey’in şahsi desteği açıkça vurgulanmıştır:

Gazetemiz bu nüshası ile ikinci senesini itmam etmiş oluyor, devam ve intişarını Sıhhiye ve Muavenet İçtimaiye Vekil-i Muhteremimiz Refik Beyefendi'nin şahsi teveccüh ve alâkasına medyun olan "Hastahane" müşarünileyhe şükran ve minnetlerini arz ve takdim, sinin-i atide muhterem meslektaşlarının teveccüh-i mahsuslarına daha ziyâde çalışacağını da samimiyetle vaad eder. ${ }^{25}$

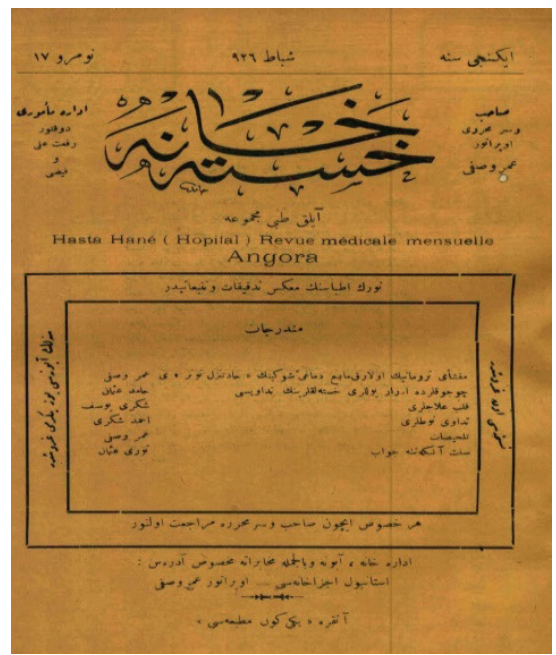

Resim 5. Op. Dr. Ömer Vasfi Bey'in sahibi ve sermuhariri olduğu Ankara'da yayımlanan Hastahane mecmuasının bir sayısının kapak sayfası (Ankara, Milli Kütüphane)

Ömer Vasfi Bey Hastahane mecmuası aracılığıyla hükûmet politikalarının destekçisi konumunu sürdürmekten ve Numune Hastanesi'nin propagandasını yapmaktan geri durmamıştır. Bir yazısında İstanbul'da bulunan bazı hekimlere sert sözlerle yüklenmiş ve Ankara'nın imkânlarının İstanbul'dan hiç de aşağı olmadığını belirtmiştir:

Kodamanların menfaatine dokunuyor galiba! ${ }^{26}$

İstanbul'un ne garip zihniyeti var hâlâ zannediyorlar ki ne var ne yok ise İstanbul'dadır. Anadolu'da yükselen ihtilal ve ink1lap gürültüleri, atılan terakki hatveleri müphem ve manasız şeylerdir. Misal mi istersiniz? İşte şimdilik isimlerini tasrih etmek istemediğimiz

“Teşekkür," Hastahane 2, 13 (Teşrinievvel 1341): ön kapak iç kısmı; "İtizar" Hastahane 2, 20 -21 (Mayıs ve Haziran 1926): ön kapak iç kısmı; “Teşekkür,” Hastahane 2, 23-24 (Eylül ve Teşrinievvel 1926): arka kapak iç kısım; “Arz-1 şükran,” Hastahane 3, 31 (Temmuz 1928): 1.

24 "Muhterem karilerimize," Hastahane 1, 12 (Eylül 1341): arka kapak.

25 Hastahane 2, 23-24 (Eylül ve Teşrinievvel 1926): arka kapak iç kısım.

26 Hastahane 1, 2 (Teşrinisani 1340): arka kapak iç kısmı. İmzasız yayınlanmasına rağmen yazının Ömer Vasfi Bey’in derginin sahibi ve mesul olması nedeniyle ve üslûben onun kaleminden çıktığı düşüncesindeyiz. 
birkaç alim-i tıbbın bazı hastalarımıza tavsiyeleri; Efendim Ankara'da mı, acaba hastane var mı? Asepsi, temizlik nasıl... bilmem yapabilirler mi... böyle tedaviler orada olamaz... Anadolu'nun birçok yerlerinde ilim, ciddiyet ve intizamla tebarüz eden müessesat-1 sıhhiye ve tıbbiye İstanbul'un o eskiden kalma rütbelerile, şarlatanlıklarile ve akla gelmedik sahabetlerle mevki tutan bir kısım etibbasının kazançlarını kırdığı için bu gibi adem-i memnuniyet emarelerinin görülmesini tabii addederiz. Haklıdırlar; çünkü İstanbul'da kendilerini sıfira indiren genç ve güzide mütehassıslardan başka bir de Anadolu'da rakipleri çıkıyor. İlme, tıbba hürmeti anlamayan bu gafil efendilere ihtar edelim ki Ankara'daki Numune Hastahanesi Sihhiye Vekâleti'nin mebzul ve müfid himmetile teçhizatça hizmet-i tıbbiyece İstanbul hastahanelerinden hiç de aşağı değildir. Çalışkan ve güzide heyet-i tıbbiyesi, hüviyet-i ilmiyece çok yüksektir. Numune Hastahanesi'nin ameliyathane ve tâkim [sterilizasyon] tertibatını, hasta teçhizatını ve temiz koğuşlarını İstanbul hastahanelerinde görmek kabil olmadığını iddia ederiz. Fenni mesaiye gelince; bu herhalde eline geçen hastalara hekimliğe yakışmayacak propagandalar yapan zavallılar için şayan-1 istifade ve ibret bir dosya teşkil eder.

Ömer Vasfi Bey, 17 Ekim 1921'de başlayan Ankara Hastahaneleri Müsamere-i Tıbbiyesi'nin ${ }^{27} 6$ Ekim 1927 tarihli toplantısında ikinci reisliğine seçilmiştir. ${ }^{28}$ Erken cumhuriyet döneminde, idari açıdan güçlü bir konumda bulunan Ömer Vasfi Bey, bu yıllarda devlet ricalinden birçok kişinin ve bu kişilerin aile efradının hekimliğini yapmıştır. ${ }^{29} 1933$ yılı Eylül ayı sonuna kadar Numune Hastanesi Başhekimliği devam etmiş, Eylül 1933 ile 19 Nisan 1937 tarihleri arasında ise aynı hastanenin I. Hariciye Kliniği’nde çalışmıştır. Ömer Vasfi Bey’in yerine başhekimliğe Dr. Refik Saydam'ın daveti üzerine Dr. Nüzhet Çevik getirilmiştir. ${ }^{30} 1937$ 'de (Mayıs ayında yapılan atamada) Şişli Etfal Hastanesi başhekimliğine Ömer Vasfi Bey’in kendi talebi üzerine atanmış olması, Dr. Refik Saydam Bey ile aralarındaki müspet ilişkinin devam ettiğinin bir göstergesidir.

27 “Ankara Hastahaneleri Müsamere-i Tibbiyesi” 17 Teşrinievvel 1337 (17 Ekim 1921) Cuma günü saat ikide ilk celsesini Müdafaa-i Milliye Vekili Refet [Bele] Bey ve Sıhhiye Reisi Miralay İbrahim Tali [Öngören] Bey ve birçok zevatın katılımıyla açmıştır. Müsamere'nin idare heyetine şu şahıslar getirilmiştir: Reis-i evvelliğe Dr. Muallim Abdülkadir Lütfi [Noyan], reis-i saniliğe Dr. Muallim Hüsameddin Şerif, kâtib-i umumiliğe Dr. Nazım Şakir [Şakar], kâtipliklere Dr. Zeki Hakkı ve Dr. Salim Bey. Askeri Tıb Mecmuası 1, 1 (Kânunuevvel 1337): 1. Müsamerelerin açılış tarihi Dr. İbrahim Tali'ye göre 7 Ekim 1921'dir. Dr. Íbrahim Tali Bey'in Günlüğ̈̈, yay. haz. Erdal Aydoğan ve Şaban Ortak (İstanbul: Arba, 2000), 80.

28 Mutad olan Ankara Müsamerelerine 6 Ekim 1927 Perşembe günü Türk Ocağı salonunda saat 14'de başlanmıştır. Riyasete Merkez Hastahanesi Sertabibi Miralay Avni, reis-i saniliğine Dr. Ömer Vasfi, kâtib-i umumiliğe Binbaşı Dr. Cevdet Tahir, kâtipliklere Yüzbaşı Dr. Reşad ve Yüzbaşı Dr. Ahmed [Röntgen mütehassısı] Beyler seçilmiştir. Hastahane 3, 25 (Teşrinievvel 1927): 16; Askeri Tıb Mecmuası 56, 11 (Teşrinisani 1927): 461.

29 Dönemin basınında vefatının ardından tartışmalara neden olan Milli Eğitim Bakanı Mustafa Necati Bey’i ameliyat eden hekimlerden biri de Ömer Vasfi Beydir. Refik Saydam'ın hekimlerin tıbbi bir kusuru olmadığına yönelik Giresun Milletvekili Hakkı Tarık (Us) Bey’e mecliste verdiği cevap ve sunduğu raporlar için bkz. “Necati Bey'in Ölümü,” Sihhiye Mecmuası 5, 22 (Kanunusani 1929): 133-140. Avusturya Sefiri August Kral'ın Aralık 1930'da geçirdiği araba kazası sonrası vücudunda çoklu kırıklar oluşmuş, Ömer Vasfi Bey ameliyatlarını gerçekleştirmiş ve Sefir 3 ay sonra şifa bularak hastaneden çıkmıştır: Bkz. 40. Yıl Münasebetiyle Ankara Numune Hastanesi, 12; Ayın Tarihi 25, 84-85 (Mart-Nisan 1931): 7307. General Kazım Özalp'in 1932'de ilkokul 3. Sınıf talebesi olan oğlu Teoman Özalp'in apandisit ameliyatını yapmıştır: İbrahim Başağaoğlu ve Eren Akçiçek, “Atatürk'ün Yurt Seyahatlerinde Ziyaret Ettiği Sağlık Kurumları,” Atatürk Dönemi Sağlık Tarihi Kongresi (1920-1938) Bildiriler (İzmir: Ege Üniversitesi Basımevi, 2009), 780. 
Ömer Vasfi Bey, 1948 yılında Türk Tıp Tarihi Kurumu üyesi olmuş ve o dönem yıllık toplanan kurumun genel kuruluna başkanlık etmiştir. ${ }^{31} 19$ Ekim 1949 tarihinde Şişli Etfal Hastanesi’nden emekliye ayrılan Ömer Vasfi Bey, 25 Ağustos 1969 Pazartesi günü vefat etmiş, 27 Ağustos 1969 Çarşamba günü İstanbul Edirnekapı Şehitliği’ndeki aile kabristanına defnedilmiştir. ${ }^{32}$ Ömer Vasfi Bey'in Şişli Etfal Hastanesi yılları ve takip eden yirmi yıllık emeklilik dönemi hakkında maalesef yeterince bilgi bulunmamaktadır.

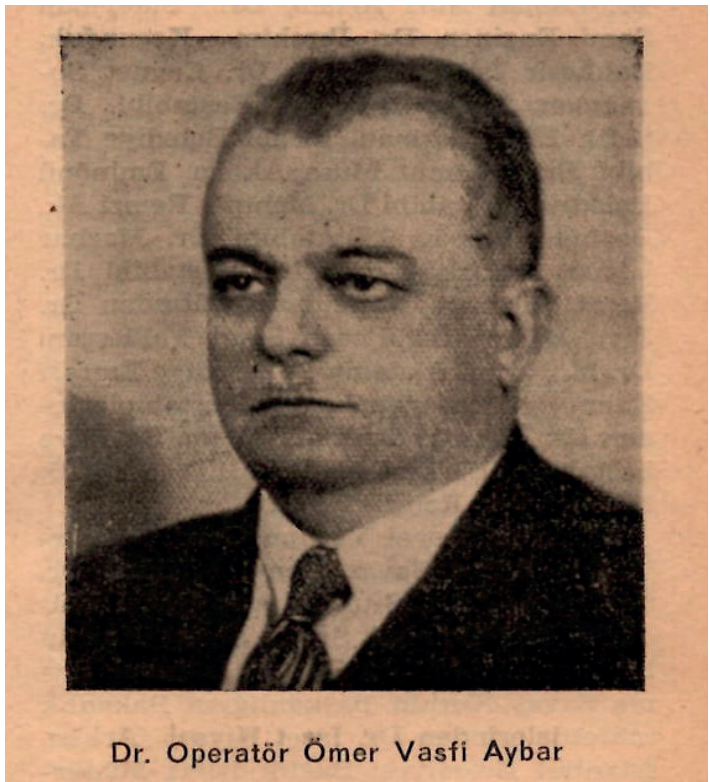

Resim 6. Op. Dr. Ömer Vasfi Aybar'ın emeklilik döneminde çekilen bir fotoğrafi (İstanbul Klinik Dersleri 2, 7 (Ekim 1949): 67).

\section{Türk Hekimi Dergisi: Fiziki Özellikleri, Yayın Hayatı, Yazarları ve Dizini}

Türk Hekimi dergisi ilk kez Bedi N. Şehsuvaroğlu tarafından "Basın tarihimizde sıhhi mevkuteler" başlıklı yayın ile tanıtılmış, derginin bir fotoğrafı da makaleye eklenmiştir. ${ }^{33} \mathrm{Bu}$ tarihten sonraki bibliyografik yayınlarda dergi hakkındaki bilgiler mezkûr yayından aynen aktarılmış, dolayısıyla dergi bugüne kadar ayrıntılı olarak incelenmemiştir. Derginin şu ana kadar görülebilen iki sayısı biri mavi, diğeri siyah bez cilt içinde olmak üzere iki takım halinde sadece İstanbul Üniversitesi İstanbul Tıp Fakültesi Tıp Tarihi ve Etik Anabilim Dalı

31 E. Kadri Unat, “Türk Tıp Tarih Kurumu’nun İlk Elli Yılının Tarihçesi,” II. Türk Tıp Tarihi Kongresi İstanbul, 20-21 Eylül 1990, Kongreye Sunulan Bildiriler içinde (Ankara: Türk Tarih Kurumu 1999), 9, 12.

32 Milliyet Gazetesi, 27 Ağustos 1969, s. 11.

33 Bedi N. Şehsuvaroğlu, "Basın Tarihimizde Sıłhi Mevkuteler" Yeni Tıp Alemi 10 (Temmuz-Aralık 1961): 484-501; Aynı yayının genişletilmiş hali için bkz. Bedi N. Şehsuvaroğlu, “Türkiye' de Sağlıkla İlgili Olarak Yayınlanan Periyodikler,” İstanbul Tip Fak. Mecmuast-36, 1 (1973): 169-198. 
Arşivi'nde bulunmaktadır. Ciltlerden biri içerisindeki dergilerde Bedi N. Şehsuvaroğlu'nun şahsi kaşesi bulunmaktadır. Yaptığımız çevrimiçi katalog taramalarında derginin Türkiye ve Türkiye dışındaki kütüphanelerde herhangi bir sayısına rastlanmamıştır. Bu nedenle dergi, son derece nadir bir dergidir.

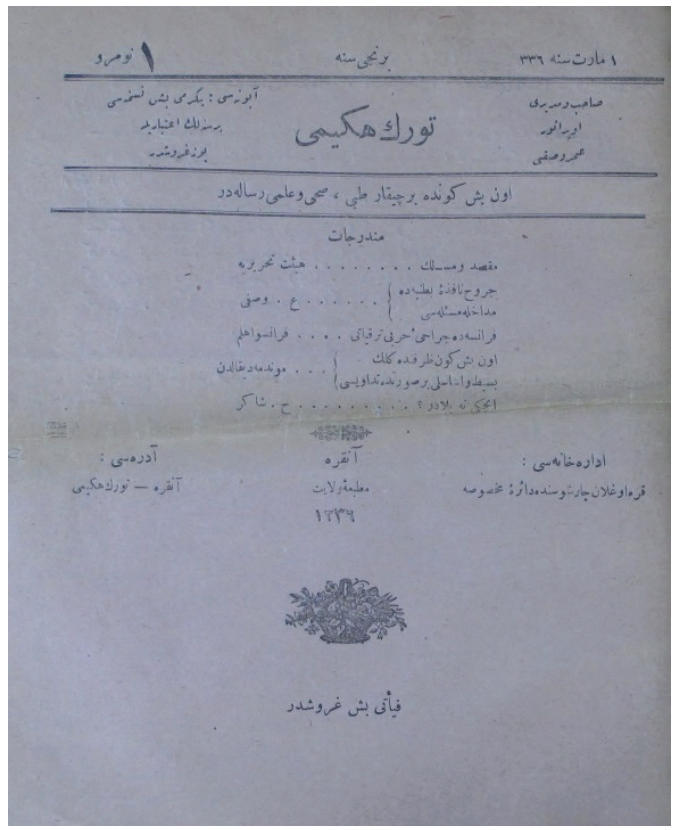

Resim 7. Türk Hekimi dergisinin 1 Mart 1336 (1 Mart 1920) tarihli ilk sayısının kapağ1 (İ.Ü. İstanbul Tıp Fakültesi Tıp Tarihi ve Etik Anabilim Dalı Arşivi).

Türk Hekimi dergisi 1 Mart 1336 (1 Mart 1920) tarihinde “On beş günde bir çıkar tıbbi, sıhhi ve ilmi risaledir” alt başlığıyla yayın hayatına başlamıştır. Derginin sahibi olan Operatör Ömer Vasfi Bey, müdürlüğünü de üstlenmiş, dergi kapağında bir yayın kurulu gösterilmemiştir. Dergi senelik 25 nüsha hedefiyle yayın hayatına başlamış, yirmi beş nüshası senelik 100 kuruş, tek sayı bedeli ise 5 kuruş olarak belirlenmiştir. Abone olmak isteyenlerin abonelik ücretlerini mukaddereli (değeri beyan edilmiş) mektup tarzında Ankara'da Şevket Ahmed Eczanesi'ne Ömer Vasfi Bey adına göndermesi gerektiği belirtilmiştir. Ankara'da Matbaa-i Vilâyet'te basılan derginin idarehanesinin adresi “Karaoğlan Çarşısı'nda Daire-i Mahsusa” olarak gösterilmiştir. Bir sayfada iki sütün yazı olarak ve bir nüshası sekiz sayfa çıkan dergi resimsizdir ve $28 \times 21 \mathrm{~cm}$ boyutundadır. Derginin amaç ve hedefleri “Türk Hekimi'nin Maksad ve Mesleği” başlıklı aşağıdaki imzasız giriş yazısı ile açıklanmıştır. ${ }^{34}$

34 Türk Hekimi, numero 1 (1 Mart 1336/1 Mart 1920): 1-2. 
"Türk Hekimi'nin Maksad ve Mesleği”

Herhangi bir firsatla ruh ve hissimizi yakından tedkike muvaffak olan bazı ecnebiler müstesna tutulursa Türk'ün meziyet ve liyâkati Avrupalılar nezdinde külliyen meçhul kalmıştır denilebilir. Türk'ü hâlâ şalvarlı, poturlu, fikir ve muhakeme nokta-i nazarından pek ibtidai bir kavim gibi telakki eden milletler pek çoktur. Hele ilim ve fen vadisinde Türk'de zerre kadar bir meziyet tasavvur olunmaz.

Avrupa'nın yanı başında asırlardan beri mahiyet-i hakikiye ve haslet-i güzidesi nâmalum bir millet halinde kalmış olmaklığımızın kusur ve kabahati bir nokta-i nazardan bizzat kendimizdedir. İstanbul'a veya herhangi bir Anadolu şehrine gelen ecnebiler Türk memleketinde yabancı muhitatla [çevrelerle] derhal tahdid olunur. Öyle muhitler ki bizi şekl-i hakikimizin dûnunda [aşağısında] göstermekle zevk-yâb olan ve bu hususda müretteb [danışıklı] planlarla çalışan âmâl [emeller] ve tasavvuratı hâricin nüfuz ve entrikalarına kaptırmış, gayr-1 Türk anasırdan müşekkel... vakar ve sekînet, âlâyişden ictinâb hasletlerine biraz ziyâdece yapışmış olan Türk, ecnebilerle temas hususunda da fazla merdümgirizdir [çekingendir]. Diğer taraftan milletimizi, milliyetimizi takdim ve teşhir edecek müessesat-1 ictimaiyyeden de mahrumuz. Hâsılı şuabat-ı ilim ve fende Balkanlı ve şark komşularımızın pek çok fevkinde bulunmaklığımıza rağmen Avrupa nazarında meçhul kalmaklığımız kendi kendimizi tanıtmak hususundaki lâkaydımızdan münbaistir [kaynaklanmaktadır].

Âlem-i medeniyetin pişvâları [önderleri] olan büyük milletlere nazaran mevcudiyetimiz hiç hükmünde ise de herhangi bir şube-i ilim ve irfanı onlar kadar temsil etmiş münevver zekâlardan da mahrum değiliz. Harb seneleri zarfinda ve mütarekeden sonra birçok ecnebi hekimleriyle temas hâsıl oldu. Müessesat-1 sıhhiyemizde fennin suver-i tatbikıyyesini [tatbik suretlerini] görerek hayretlerini izharla beraber bunları yapanların Türk olup olmadıklarını da cidden tâmik ve tedkik ediyorlardı [araştırıyor ve inceliyorlardı]. Musul'a giren İngiliz ordu etibbası ordudaki labaratuvarlarımızı, mesai-i fenniyeyi me'mûlün [umulanın] fevkinde görüp doktorlarımızı takdir etmişlerdir. Esna-yı harpte Diyarbakır'a gelen Alman ve Avusturyalı etibba-yı güzide bir Türk doktoru olan Hüseyin Baydur'un röntgen klişelerini Berlin ve Viyana müessesat-1 şuaiyyesinin mahsul-i nefâsetleriyle [1şın merkezlerinin güzel klişeleriyle] mukayese ederlerdi. Daha geçenlerde külliyetli veba aşısı istihsali için Dersaadet'de alelacele tanzim edilen bir darülistihzarı ziyaret eden İngiliz ve Fransız etibbası doktorlarımıza karşı samimi ve ciddi takdirlerini alenen izhar eylemişlerdir. Fakat bu temas ve müşahedeler ummandan birer katredir; milletimizin liyâkat ve kabiliyeti hakkında efkâr-1 umumiyye-i medeniyeye bir fikir verdirmeğe kâfi gelemez. Hâl-i hazırda milletlerin mevki-i ictimaiyyesi ilim ve fazilet bâbında kazandığı notlarla tayin ve tesbit olunuyor. Değil ecânib kendi kitle-i milliyemiz bile münevveranının yüzümüzü ağartacak fezâil-i ilmiyelerinden bî-haber bulunuyor. Meselâ milletimiz içinden yetişen doktorlarının derece-i ilim ve iktidarına karşı haiz-i malumat değildir. Bir hakikat olarak iddia eyleriz ki sunûf-1 güzideye mensub etibbasının adeden fazlalığından sarfınazar lâlettâyin [rastgele] bir Türk hekimi alelade bir ecnebi hekiminden asla aşağı değildir. Diğer şuabat-1 ilim ve fende de keyfiyetin böyle olduğuna kanaatimiz vardır.

O halde maraz, derd nedir ki makine muntazaman işlemiyor; doktorlarımız tek tük firsatlarla inkişaf eden hususattan mâadâ muntazam bir iş göremiyorlar? Ferd itibarile olan faziletlerimiz manzume haline gelince neden dûçar-1 akamet oluyor? 
İşte "Türk Hekimi” mesai-i ilmiyesile Türk doktorunun ferdi meziyetlerini vatanına ve harice tanıtmağa bu veçhile milli varlığımıza hizmete çalışacağ 1 gibi umur-1 sıhhiyemizin tarz-1 idaresindeki yolsuzlukları da kanaatince tenkid edecek ve bu bâbdaki münâkaşat-1 ciddiyeye sahifelerini açık bulunduracaktır. Türk milletinin de diğer milletler misillü fenn-i tıbbı kemâlile tahsil ve temsil eden dimağlardan mahrum bulunmadığını, göze çarpacak iş yapılamamasının teşkilâtımızdaki noksandan ve doktorların devâir-i hükûmette maruz kaldıkları müşkülâttan inbias eylediğini [kaynaklandığını] mukni' [ikna edici] ve maddi delillerle neşr ve izah edecektir.

Sırf ilmi hususattan mâadâ hususi bendler ayırarak Türk köylüsüne sıhhatin kadrini, hastalıklardan tarz-1 tahaffuzu [korunma tarzını] açık bir lisanla bildirmek de makasıdımızdan [maksatlarımızdan] biridir.

Gazetemizin devamı için maddi fedakârlık göze alınmakla beraber meslekdaşımız bulunan rüfeka-yı muhteremenin muavenetlerinden müstağni değiliz.

Memlekette fenni, ilmi müdafaa; fen ve ilim adamlarının sıyânet-i hukukuna çalışmak ve bi'n-netice yaralı bir kuş halinde çırpınan zavallı felâketzede milletimize rehâ-kâr [kurtarıc1] ve serî bir tarz-1 muavenet bâbında mücahede eylemek azminde bulunan (Türk Hekimi)'nin her sınıf vatandaşlarımızdan muavenet göreceğinden şübhemiz yoktur. ve minallahi't-tevfik.

Dergi, aynı dönemde Afyon'da yayımlanan Doktor Mecmuası'nın okurlarına da tanıtılmıştır. ${ }^{35}$ Derginin ikinci sayısı 15 Mart 1920'de yayımlanması gerekirken 26 Nisan 1336 (26 Nisan 1920) tarihinde yayımlanmış ve bu sayının başlığından "On beş günde bir çıkar” ibaresi kaldırılarak “Tıbbi, sıhhi ve ilmi risaledir” alt başlığı kullanılmıştır. Derginin ikinci sayısının gecikmesi bir itizar [özür] paragrafı ile açıklanmış, Vilâyet Matbaası'ndaki meşguliyetin baskıyı geciktirdiği ve bu durumun telâfi edileceği bildirilmiştir. ${ }^{36}$ Derginin ilk sayısının arka kapağında, Frengi ve Bel Soğukluğu Mütehassısı Dr. Osman Yaşar Bey’in bir reklamı, Doktor Muhittin Celâl Duru Bey'in “Isıtma (sıtma) Nedir?” isimli ibtidai mektepler ve köylüleri bilgilendirmek için kaleme aldığg eser ile Ankara Şevket Ahmed Eczahanesi’nin birer reklamı yer almaktadır. ${ }^{37}$ Derginin ikinci sayısında askeri tıp tarihimiz açısından dikkatle

35 “Ankara'da Türk Hekimi namile heyet-i tıbbiyenin idare ve tahriri altında on beş günde bir olmak üzere bir mecmua-yı tıbbiyenin intişar ettiğini idaremize gelen ilk nüshasından anladık. Refikimizce mündericatı bütün meslekdaşlarımız için çok şayan-1 istifadedir. Muvaffakiyetler temenni etmekle beraber karilerimize tavsiye ederiz.” Bkz. "Türk Hekimi," Doktor Mecmuası numero 3 (1 Nisan 1336 / 1 Nisan 1920): iç kapak sayfaları, 3.

36 O dönemde Ankara Vilâyet Matbaası'nda basılan gazetelerden biri 10 Ocak 1920'de yayın hayatına başlayan ve Milli Mücadele'nin yayın organlarından biri olan Hâkimiyet-i Milliye gazetesidir.

37 Şevket Ahmed Bey'in Belediye Eczanesi'nde hekim muayenehanesi bulunmaktaydı ve eczaneye devam eden tabipler şunlardı: Asabiye mütehassısı Rifat Bey, göz tabibi Şerafeddin Bey, bakteriyolog [Evliyazade] Adil Bey, zühreviye tabibi Osman Yaşar Bey, operatör ve nisaiye mütehassısı Ömer Vasfi Aybar Bey, emraz-1 mütenevvia mütehassısı Ksenidis Bey, dâhiliye tabibi Mahir Bey, dâhiliye ve çocuk hastalıkları tabibi Muhittin Celal Duru Bey, dâhiliye ve viladiye mütehassısı Nedim Bey. Türk Hekimi numero 1 (1 Mart 1336/1 Mart 1920): arka kapak. 
okunması gereken, Ömer Vasfi Aybar Bey’in Çanakkale cephesindeki cerrahi faaliyetlere dair hatıralarını içeren "Harb-i umumide memleketimizde faaliyet-i cerrahiye" başlıklı makalesi yayımlanmıştır. [Ek-1]

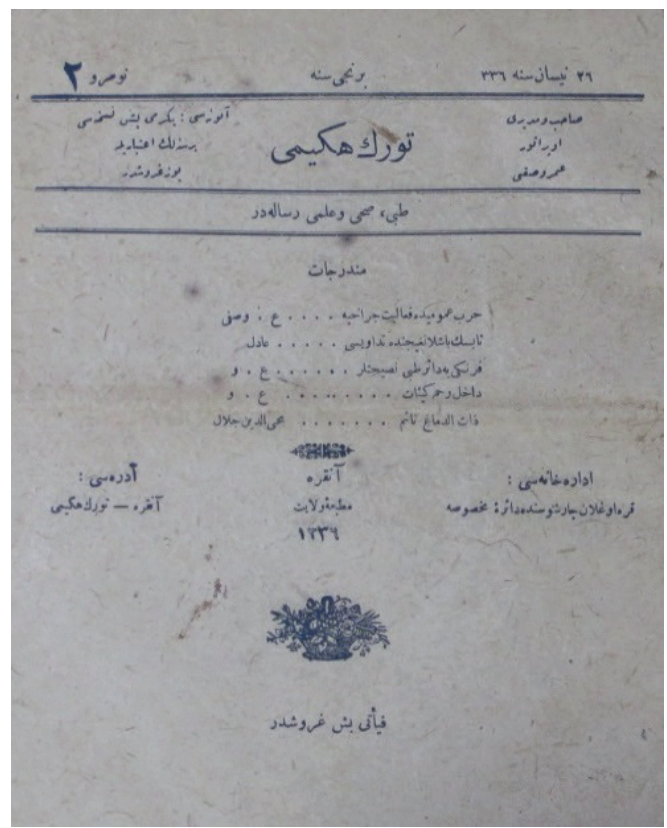

Resim 8. Türk Hekimi dergisinin 26 Nisan 1336 [26 Nisan 1920] tarihli ikinci sayısının kapağı (İ.Ü. İstanbul Tıp Fakültesi Tıp Tarihi ve Etik Anabilim Dalı Arşivi).

Dergide, Operatör ve kadın hastalıkları mütehassısı Dr. Ömer Vasfi Aybar'ın; Dâhiliye ve çocuk hastalıkları mütehassısı Dr. Muhittin Celâl Duru'nun; ${ }^{38}$ Bakteriyolog ve Cilt hastalıkları mütehassısı Dr. Hamid Şakir Şakar'ın; Bakteriyolog ve Cilt hastalıkları mütehassısı Dr. [Evliyazade] Adil'in çeviri ve telif makaleleri bulunmaktadır. Derginin ikinci sayısından sonraki akıbetini bilemiyoruz. Ömer Vasfi Bey’in yukarıda belirtildiği gibi Haziran-Temmuz 1921 tarihine denk gelecek bir zamanda Giresun Memleket Hastahanesi’ne atandiğ hesaba katılırsa derginin bir ihtimal Haziran-Temmuz 1921 tarihine kadar yayımlandiğ 1 düşünülebilir. Ancak Ankara'daki matbaa imkânsızlıkları, 23 Nisan 1920'de TBMM'nin açılışı ile Milli Mücadele'nin merkezi olan Ankara'da daha hareketli günlerin yaşanmaya başlaması Türk Hekimi'nin yayın hayatının ikinci sayısıyla noktalanmış olması ihtimalini kuvvetlendirmektedir.

38 Muhittin Celâl Duru Bey ile ilgili ayrıntılı bilgi için bkz. Ali Birinci, “Türk Yurdu Kalemleri: Dr. Muhittin Celal Duru," Türk Yurdu sayı 352 (Aralık 2016): 64-69. 
Tablo 1. Türk Hekimi Dergisinin Dizini

\begin{tabular}{|l|c|}
\hline Numero 1, 1 Mart 1336 (1 Mart 1920) & Sayfa \\
\hline Türk Hekimi'nin maksad ve mesleği [Hey’et-i tahririye] & $1-2$ \\
\hline $\begin{array}{l}\text { Cerrahî sütunumuz: Cürûh-1 nâfize-i batniyyede müdahale mes'elesi } \\
\text { (Penetran batın yaralanmalarına müdahale meselesi), Dr. Ömer Vasfi [Aybar] }\end{array}$ & $2-3$ \\
\hline $\begin{array}{l}\text { Fransa'da cerrahi-i harbi terakkiyâtı } \\
\text { Dr. François Helme'in Kânun-i sani 1920 tarihli risalesinden çeviri }\end{array}$ & $3-6$ \\
\hline On beş gün zarfında kellik basit ve esaslı bir tedavisi, Le Monde médical'den çeviren Dr. Adil & $6-7$ \\
\hline İcki ne belâdır?, Dr. Hamid Şakir [Şakar] & $7-8$ \\
\hline Numero 2, 26 Nisan 1336 (26 Nisan 1920) & Sayfa \\
\hline Hasbihal-i fenni: Harb-i umumide memleketimizde faaliyet-i cerrahiye, Dr. Ömer Vasfi [Aybar] & $1-3$ \\
\hline $\begin{array}{l}\text { Tabes'in [Tabes Dorsalis] başlangicında tedavisi (mabadı var), } \\
\text { Le Monde médical'den çeviren Dr. Adil }\end{array}$ & $3-4$ \\
\hline Frengiye dair tıbbi nasihatler, Dr. Ömer Vasfi [Aybar] & $4-5$ \\
\hline Zâtü'd-dimağ-1 nâim [Letarjik Ensefalit], Dr. Muhittin Celâl [Duru] & $5-7$ \\
\hline $\begin{array}{l}\text { Dâhil-i rahim-i key'at [İnrauterin koterizasyonlar], } \\
\text { Le Monde médical'den çeviren Dr. Ömer Vasfi [Aybar] }\end{array}$ & $7-8$ \\
\hline
\end{tabular}

\section{Sonuç}

Ömer Vasfi Aybar, ihtisasının ardından kendini savaşın ortasında bulan ve özellikle Çanakkale Cephesi'nde önemli hizmetler sunmuş bir cerrahtır. Cumhuriyet sonrasında Ankara Numune Hastanesi ve Şişli Etfal Hastanesi'nin başhekimliğini üstlenmiş, bazı derneklerin yönetimlerinde bulunmanın yanında birçok tıp dergisinin de yayınlanmasına doğrudan veya dolaylı katkılar vermiştir. Hayatının 1919-1924 arasındaki kritik dönemi yeterince bilinmemektedir. Cumhuriyet öncesinde yani genç bir cerrahken çeşitli siyasi/ içtimai polemiklerin içine girdiği, Cumhuriyet sonrasında ise polemikten ve siyasetten uzak bir hayat sürdüğü anlaşılmaktadır. Ömer Vasfi Bey’in İngiliz Muhipleri Cemiyeti ilişkisi nedeniyle Ankara Hükûmeti tarafından kabul görmeme tehlikesini tıbbi kariyeri/çalışkanlığı, şahsi ilişkileri ve o dönem genç bir hekim olması nedeniyle atlattığı anlaşılmaktadır. Nitekim Ankara'da bulunduğu dönem içerisinde Atatürk'ün tedavisi dâhil devlet ricalinden birçok zevatın tedavisini/ameliyatını bizzat gerçekleştirmiştir.

Dr. Muhittin Celal Duru, Op. Dr. Ömer Vasfi Aybar ve Dr. [Evliyazade] Adil'in İngiliz Muhipleri Cemiyeti'nin Ankara Şubesi kurucuları arasında olması ve sonrasında Türk Hekimi'ni birlikte çıkarmaları, Türk Hekimi'nin birtakım siyasal kaygılar arka planında yayımlandığ 1 izlenimini vermektedir.

21 Nisan 1919 tarihli Abdullah Cevdet'e hitaben yayımladığı mektuba göre, Ömer Vasfi Bey, milliyetçiliğin dar siyasi hesaplaşmalardan çıkarılıp ilim-irfan sahasına taşınması gerektiği görüşündedir. Tespit edilebilen eserleri incelendiğinde de [Ek-4] üretken bir hekim olduğu ve bu anlayış doğrultusunda hareket ettiği açıkça görülmektedir.

Türk Hekimi dergisinde, harp cerrahisi, zührevi hastalıklar, kadın-doğum hastalıklarına dair çeviri ve telif makaleler göze çarpmaktadır. Türk Hekimi, yayın heyeti tarafından 
açıklanan hedeflere ulaşabilecek bir yayın hayatına sahip olamamıştır. Derginin elimizde yalnızca iki sayısı mevcuttur. Anadolu'da Cumhuriyet öncesinde yayımlanan tıbbi dergilerin sayıca az olması, koleksiyon eksiklikleri ve özellikle Türk Hekimi'nin yayınlanma şartları ve sebepleri de dikkate alındığında derginin tıp tarihi açısından kıymeti daha da artmaktadir.

\section{Ek 1. Ömer Vasfi Aybar'ın “Harb-i Umumi'de Memleketimizde Faaliyet-i Cerrahiye" başlıklı yazısı (Türk Hekimi, sayı 2 (26 Nisan 1336 / 26 Nisan 1920): 1-3)}

Hududlarımızda harbin hûnin-i mücâdelâtı [kanlı mücadeleleri] başladığı zaman etibba ve cerrahlarımız, cerrahi-i harbi [harp cerrahisi] muhafazakârlık esasına müsteniddir, düstûr-1 marufuna bel bağlamış ve bi'n-netice hatt-1 harb cerrahisini sıhhiye bölüğü ve seyyar hastahane ile mahdud ve basit bir tarzda telakki eylemişlerdi. Şüphesiz fen âleminin de telakkisi böyle idi. [Julius] Wieting Paşa'nın eldeki risaleleri, ${ }^{39}$ sıhhiye bölüğü ve seyyar hastanelerde yapılacak müdahalât-1 ameliyyeyi [pratik müdahaleleri] adeden tesbit ve tahdid eylemiyordu. Gülhane'deki harb konferansları da hep bu resail mündericatını [kitapçıkların içeriklerini] telkin ve tahkim içindi. Sıhhiye bölükleriyle seyyar hastahanelere aid malzeme-i tıbbiye listeleri de ona göre tanzim edilmişdi. Cürûh-1 harbiye [harp yaralanmalar1] denilince yalnız betr ve nezf mesailinden [ampütasyon ve kanama meselelerinden], haza'-1 şiryân-1 şezen [trakeostomiden] ve bir de haza'-1 ihlîl-i harîcî [üretrotomi ekstern]'den başka bir şey görülmüyordu. Müdahalât-1 mühimme-i sâire hep menzilde [cephe gerisinde] görülecek hidemat [hizmetler] meyanında idi.

Çanakkale'de ilk patlayan muhtelifü'l-cins düşman mermilerinin pişgâh-1 imdadıma koyduğu mecruhin [yardım için önüme koyduğu yaralıların] içine atıldığım zaman, yirmi dört saate varmadan hayatı söndüren "septisemiler", "gazlı gangrenler", ufak bir fetha-i duhul gavrında [giriş deliği zemininde], "müntin ve mütefettit küsurat" [enfekte ve parçalı kırıklar] hiçbir tavsife uymayan "cürûh-i vasia [geniş yaralar]"...ilh. Menâzır-1 müdhişe ve müellimesi [elemli ve dehşetli manzaralar] karşısında kalmışdım. Muhafazakârlık düsturunu veyahud müdahalât-ı mahdude [kısıtlı müdahaleler] müsâadekârlığını düşünmeksizin fakültenin kaloriferli ve muhteşem ameliyathanesinde nasıl çalışıyorsam ol-veçhile hareket eyledim. Gerek cürûh-1 harbiyeye müdahalât-1 ibtidâiyyede bulunmak [harp yaralarına ilk müdahalede bulunmak] ve gerek azayı ve vazifelerini vikâyeten [koruyarak] hareket etmek... Hâsılı her ne telakkide olursa olsun muhafazakârlık medlûlünün [mefhumunun] cerrahi-i harbide vâcibü'l-imtisal [uyması vacip] ve masunü'l-indiras bir umde-i esasiye olarak telakkisinden tevellüd edecek mehaziri derpiş ederek [yok olmaktan korunması gereken esas ilke olarak telakkisinden doğacak zararları göz önüne alarak] intânat [enfeksiyonlar] hakkındaki esasları tevfikan çalışmakdan doğru bir program olamayacağına karar vermek için çok zaman geçirmedim. Yaralar öyle bir şekl-i harabiyet arz ediyordu ki iki gün sonra açılmak üzere bir pansuman ayırmak mümkün olamıyordu; ekserisine şakklar yaparak [yaralar açılarak], şezaya [şarapnel], mermi, elbise parçaları ve ecsam-1 ecnebiye-i saire çıkarmak; birçok betr ve tesmimler [ampütasyon ve disartikülasyonlar] yapmak... Hâsılı az çok müdahalâtda bulunmak ve her gün tımarları [pansumanları] değiştirib sıkı bir nezaret ve kontrol altında bulundurmak icab ediyordu. Hem mecruhin beş altı, azami on iki saat sonra seyyar hastanemize geliyorlard.

39 [Julius] Wieting Paşa’nın anılan risaleleri, Gülhane başhekimliği zamanında başlattığı 'Gülhane Seririyat Külliyat Mesaisi’ adındaki yayın dizisi içinde yayınlanmıştır: Rehber-i Cerrahi-i Harbi, Gülhane Seririyat Külliyat Mesaisi 18 (İstanbul: Ahmed İhsan ve Şürekâsı Matbaacılık, Teşrinievvel 1330 / 1914), 54 s. ve Cürûh-ı Harbiyeden Mütevellid Tagayyürat-ı Vazifeviyenin Tedavi-i Muahharası Hakkında Rehber, Gülhane Seririyat Külliyat Mesaisi 19 (İstanbul: Ahmed İhsan ve Şürekâsı Matbaacılık, Kanunusani 1330 / 1915), 75 s. 
Açık ve müntin cürûh [enfekte yaralar] ile uğraşırken en temiz sandığımız, haricen [dışında] zerre kadar alâim-i iltihab [iltihap alameti] göstermeyen cürûhda tetenos ve evsaf-1 malumesiyle gazlı gangrenler mühim bir yekûnda olmak üzere tezahür ediyordu. Bunlara karşı serum, şukûk-1 vasia [geniş kesi] ve betr ve tesmimlerle [ampütasyon ve disartikülasyonlar ile] mücadele ediyorduk. Serumun şafi bir tesiri görülemiyordu, diğer müdahalâtda intan-1 umumiyenin [umumi enfeksiyonların] önünü almak bazen kabil olamıyordu. Mamafih umumun telakkiyâtına zıdd bulunduğu cihetle elimden bıçağın düşmemesi bâis-i kıl ü kal [dedikoduya neden] olmağa başlamışdı! Yaptığım ufak büyük binlerce müdahalâtda âmil-i intan [enfeksiyon faktörü] olarak mermi, elbise parçaları, taş, toprak... gibi şeyler bulduğum cihetle ileri hidemat-1 sıhhiyede cürûhu, bilhassa bomba ve top yaralarını intan [enfeksiyon] alametleri görülmese bile, iyice temizlemek, icabında şakklar yapıp [yaraları açıp] imkân müsaid olduğu kadar ecsam-1 ecnebiyeyi [yabancı cisimleri] ayıklayarak muzâdd-1 taaffünatla [antiseptiklerle] tathir ve drenaj yapmak, anaerobik bir intan olan gazlı gangren ve tetenos'a karşı vâkî [koruyucu] bir suretde de mücadele eylemek... icab ettiğini mevki-i müstahkem sertababetine bâ-rapor bildirdim. Maydos [Eceabat] bombardımanı raporumun suretini de mübeddil-i remad ettiği için [küle çevirdiği için] aynen derç mümkün olamadi. ${ }^{40}$ Muhafazakâr bir heyet-i etibba bu raporu reddetmişdi. Bilâhare siper muharebatının inkişâfı [siper savaşlarının başlaması] ile vakayi [vakalar] daha ziyade dehşetengiz olmağa başladı.

Harbin başlangıcından itibaren yedi ay geçmişti... Meydanda bu gibi şeyleri görebilmekle müvekkel [vekil tayin edilen], ciddi bir ihtisas sahibi görülmüyordu. Bazı kıymetli arkadaşlarımız, siperlerde veyahud mevkiin müsaadesizliği ve harbin şiddeti hasebile bi'z-zarur hiçbir yaralı tutamayan ve daima taze yara karşısında bulunulan sıhhiye bölüklerinde, alelade bir sıhhiye çavuşu vazifesini görüyorlardı... Kat'iyyen mazeret teşkil edemeyecek sebeplerle ağır mecruhini [yaralıları] bile hemân vapurlara koyup sevk ettirmek, şikâyeti mucib olmamak için hilâf-1 fen hususata [bilimsel olmayan hususlara] müsaade etmek, sıbg-1 iyoddan [tentürdiyottan] başka bütün muzâdd-1 teaffünü [antiseptikleri] (müvellidü'l-humûzalı su [oksijenli su], balsam-1 Peru [Peru balsamı], iyodoform....ilh ) bir emr-i mahsus-1 garib ile seyyar hastanelerden toplatmak... Bütün bu facialar karşısında orduda derd anlatacak bir mihrab-1 müracaat yok gibi idi. Feci ve elemli günler tevâli edib [devam edip] duruyordu. Birinci nüshamızdaki terakkiyât-1 cerrahiye makalesinde görüldüğü üzere Fransa Harbiye Nazırı sırf bu maksadla hatt-1 harbe [savaş hattına] heyetler sevk ettiği halde bizde muallimler, sahib-i nüfuz ve salâhiyetdâr mütehassısin-i askeriye [askeri uzmanlar], merkezlerden hâlâ ayrılamıyorlardı. Yeni harbin icabatından olarak yaralarda görülen hâlât-1 dehşet-nisâr [dehşet saçan haller], yapılan fenni hatalar kimseyi alâkadar etmiyordu. Neden sonra, galiba İstanbul'a çok cenaze çıktığı için merkezden ağır mecruhinin vaktinden evvel menzillere sevk edilmemesi acı bir ihtarname ile emredildi. Fakat merkezin âgâh olmadığı daha ne hatalar yapılıyordu?

Yedinci aydan sonra Çanakkale Ordusu'nun en mühim bir kısmı, Cenub Grubu, muhterem ve pek büyük olan bir üstad-1 fazilet-mendin [faziletli üstadın] Miralay İbrahim Tali [Öngören, 1875-1952] Beyefendi'nin riyâset-i sıhhiyesi ile şerefyâb oldu. Müşarünileyh karargâhlardaki müşavir [danışman] cerrahlardan ve k1ymetdâr operatörlerimizden Murad [Cankat, 1886-1963] ve Kemâl Cemil [Keskinel] Beyleri bilfiil işbaşına davet etti. Ve o zamandan itibarendir ki müşahedat-1 ciddiyenin tevlid ettiği tetabuk-1 efkâra tebean [ciddi müşahedelerin neticesinde oluşan fikirlerle uyaşan] Grub'un her tarafinda aynı tarzda çalışılınca daha fazla mecruh kazanmaya [yaralı kurtarmaya] başladık.

Anafartalar'da Sihhıye Reis-i Gayuru Operatör Kaymakam Hüseyin Bey [Dr. Hüseyin Hüsnü Paşa, 1883-1930] her bomba yarası derhal açılmalıdır, fikrini ta ibtidadan beri müdafaa ederek rüfaka-yı mesaisine [mesai arkadaşlarına] "cürûha ibtidaen adem-i müdahale" [yaralara başlangıçta müdahale

40 Ömer Vasfi Aybar, Dokuzuncu Fırka Seyyar Hastanesi operatörü iken geçici olarak Çanakkale Merkez Hastanesi'nde çalışmıştır. Orhaniye, Seddülbahir ve Kumkale istihkâm mevkilerinin bombardımanı sonrası Maydos Hastanesi'ne gönderilmiştir. Ömer Vasfi Bey’in Maydos bombardımanı hatıraları için bkz. "Çanakkale Savaşlarında Maydos Bombardımanı," Hayat Tarih Mecmuası 1, 2 (Mart 1967): 19-23. 
etmemek] fikrine saplanmaksızın çalışmayı tavsiye ediyordu. Bir müddet sonra bu Grub'da çalışırken Arıburnu Grubu'nun Ağır Mecruhin Hastahanesi'nde muhafazakârlığı ileri sürerek cürûh-1 kıhfiyede [kafatası yaralarında] saçları bile tıraş etmenin günah-1 kebairden addedildiğini, gazlı gangrenlerin permanganat pansumanlar ile tedavi edilmekde bulunduğunu yine orada bulunmuş arkadaşlardan duyunca hayretlere müstağrak kalmıştı. Bir gün hastanemizi ziyarete gelen Gülhane Seririyatı muallimlerinden Operatör [Friedrich] Brüning Bey tepenin birinde son terakkiyât tatbik edildiği halde, Arıburnu Hastahanesi'ni göstererek, diğerinde kurun-1 vusta desâtir-i cerrahiyesi [orta çă̆ cerrahi düsturlar1] hüküm sürüyor, demekle pek acı bir tenkidde bulunmuşdu. Hâsılı Çanakkale Harbi hitama erinceye kadar her Grub'daki cerrahi faaliyetleri görerek mesaiyi tevhid ve tanzim ve teftiş edecek bir dimağ-1 salahiyetdâr görünmemiştir.

Brüning ve ondan evvel Muallim Breslav Almanya'da bomba ve top cürûhuna karş1 hatt-1 harbde tatbik edilen müdavat-1 hususiyeyi "cürûhu temizleme ameliyesinin" ehemmiyetini bir iki kelime ile söyleyerek harekâtımızdaki isabeti teyid ettiler. Almanya seyahatlerinden son terakkiyât-1 cerrahiyeyi ordumuza nakl ve tamim hususunu ihmal eden rüesa-yı sıhhiyemize karşı tarih-i harb-i sıhhi'miz her halde bir bend-i tenkidkâr ayıracakdır.

$\mathrm{Bu}$ hareketleri kayd etmekliğim sernamemize [başlığımıza] sadık kalmak içindir. Vakayi ve hadisatın hatt-1 harbde bilfiil alın teri dökerek çalışanlara ilham ettiği husûsatı -faraza bir silsile cürûh-1 harbiyenin temizleme ameliyesi gibi- ecnebi resail-i fenniyesinde terakkiyât-1 muhimme faslında okuyoruz. Demek ki muhafazakârlık fikrini sarsan telakkiyât-1 cedide ordumuzda da müşadehat-1 vakayi eyleyebilirmiş. Fakat ordunun arkasında istatistikleri ciddi bir endişe ile okuyubda âlât-1 harbiye-i cedidenin tahribkâr cürûhuna karşı mübarezeyi [mücadeleyi] temin için, sıhhi ve gayr-1 sıhhi ümerânın [subayların] nedretiyle bî-baht kalmışız.

Memleketimizde menzil cerrahisine mütedâir olmak üzere muhterem operatör Kemâl Bey'in muvaffakiyetkâr müdahalâtını ve kıymetdâr mütalaat-1 fenniyeyi muhtevi risaleden başka bir eser-i tıbbi veya cerrahi neşr olunmamıştır. ${ }^{41}$ Çanakkale'deki müşahedatımı tesbiten Diyarbakır'da neşr eylediğim bir risaleyi de, câ-yı münakaşa [münakaşa mevzuu] bazı hususatı muhtevi olmak cihetle, bu zümreden addedersek fikr-i fennimizin derecesi anlaşılmış olur.

Ne garbın yeniliklerini görüyor ve ne de memleketimizdeki iyi veya fena hususata karşı bir alâka gösteriyorduk. Haleb'in o meşhur menzil hastahanelerinde mütekayyıh-1 cürûh-1 mefasılı [irinli eklem yaraların1], küsur-1 mütefettite-i müntineyi [enfekte parçalı kırıkları] hafif mecruhin diye ayırıp tımarcı neferatın eline bırakanların, gazlı gangrene permanganat pansumanı tatbik edenlerin farkına varamadığımız gibi hatt-i harb cerrahisinde yeni bir esas üzere çalışmak icab ettiğinde gafil kaldık. İstanbul'dan senelerce ayıramadığımız mütehassısları, hocaları ziyaret kasdıyla olsun ordulara göndererek veyahud garbın telakkiyât-1 cedidesini tamim ederek faaliyet-i cerrahiyemizi yeni esaslar üzerinde tedvir mümkün olamaz mı idi? Çanakkale'de Ağaderesi'nde sardığım bir taraf-1 süfli [alt ektremite] alçısını üç ay sonra el dokunmamış bir halde Fenerbahçe Hastahaneleri'nde görmekle hayret etmiştim. Mezkur hastahaneye mesleğine aşık bir doktor ayağı basmadığını ifham eden bu hale karş1

41 Anılan kitabın künyesi şöyledir: Dr. Neşet Osman [Usman] ve Op. Dr. Mehmed Kemal [Öke], Gümüşsuyu Hastahanesi Mesaisinden 1 - Cerrahi-i Harbiyeye Dair Malumat ve Müşahedat (İstanbul: Arşak Garoyan Matbaası, 1331 [1915]. Kitap, 2012 yılında Yetkin İşçen ve Necmettin Özçelik tarafından yayına hazırlanmıştır (Neşet Osman [Usman] Mehmed Kemal [Öke], Cerrahi-i Harbiyeye dair Malumat ve Müssahedat. 18 Nisan'dan 30 Ağustos 1331'e Kadar Hastahaneye Duhul Eden Mecruhin Üzerinde Yapllan Tedkikat ve Tedavi ile Bazı Nadir ve Müfid Vekayi, [2. bs.] diliçi çev. Yetkin İşcen, Necmettin Özçelik, İstanbul: Gümüşsuyu Hastanesi Yayınları, $2012(12 \times 21 \mathrm{~cm}, 181$ s.).). 2012 yılında yayına hazırlanan kitaptan 4 yıl sonra bir başka yayın yapılmış ancak hazırlanan bu kitaba herhangi bir atıf yapılmamışıır: Müesser Özcan ve Hatice Demir Küreci, "Savaş Cerrahisi Tarihimizden Önemli Bir Belge: Cerrahi-i Harbiye Dair Malumat ve Müşahedat," Tarih Okulu Dergisi (TOD) 9, 25 (Mart 2016): 735-745. 
bilmem ki ne denir? Bizzat fakültede aylar geçtiği halde tesbit olunmamış umk-1 cerihada şezayası [derin yarada şarapnel] yüzen küsur [kırık] dahi gördüm.

Seyyar hastahanelerde muzâdd-1 teaffün edviyenin [antiseptik ilaçların] lüzumunu orduya esmâ' edinceye kadar [duyuruncaya] iyice zahmet çekmek icab etti, harb yarası denince "Mauser" kurşununun bir tarafdan girip diğer tarafından çıkmaması gibi basit bir şey telakki olunuyordu. Ve buna karş1 da sıbg-1 iyod [tentürdiyot] kâfi idi. Merak edib de yeni cürûhu gören bilfiil çalışan mafevklere [rütbelilere] nadir rast gelirdik.

Hâsılı harbde her ordu ve hastahanede kendi idrak-1 fennisine göre çalışmış, merkez tanzim-i mesai ve tenvir hususunda bir vazife göremediği gibi hocalarımız, mütehassıslarımızda terakkiyât-1 cedide ile alâkadar olmamış; bu harbde terakkimiz Balkan Harbi'nin mahûd [malum] yaş pansumanlarını kuru pansumana tahvilden ibaret bulunmuşdur. Ömer Vasfi.

\section{Ek 2. Ömer Vasfi Aybar'ın, annesi Zekiye Hanım'a uyguladığı operasyonu sonrasında yayınladığı olgu sunumu: “Acilen Müdehaleyi Müstelzim Bir Verem-i Batni [batın tümörü] Vakası $^{42}$ (Darülfü̈nun Tıb Fakültesi Mecmuası 2, 2 (Teşrinievvel 1335 / 1919]): 88-90)}

Hasta validemdir. Sinni altmış, bünyesi zaif fakrüddem [anemik]. Dokuz seneden beri karnında bir veremin [tümörün] mevcudiyetinden müşteki. Verem bir elma cesametinde mahsus olduğu günden

42 Bu vakanın hikâyesi ayrıntılı olarak yayınlanmıştır. Bkz. Muhittin Celâl Duru, "Büyük Bir Muvaffakiyet," Mefkûre sayı 6 (9 Haziran 1335 [1919]: 3. Yazıda, Ankara Merkez Hastanesi’ne artık liyakatli hekimlerin geldiği belirtilmekte ve Vali Muhittin Paşa'nın hizmetleri övülmektedir. Bu yazının Latin harflerine transkripsiyonu burada verilmektedir: "Büyük Bir Muvaffakiyet - Vilâyet muvazene-i hususiyesinin sıhhi müessesata ayırdığı bütçe birçok vilâyetlerinkinden zengin olduğu halde hatta merkez hastasının bile ciddi bir hizmet göremediğini ve ammenin efkârında hürmetli ve namuslu bir mevki kazanamadığını görenler pek derin teessüflerle içlerini çekiyorlardı. Filhakika para ve alet (otomatikman) iş göremez, bunları kullanacak zekâ ve irfan ister. Son aylarda hakikaten tevfik-i hareket olunarak bütçenin tevdii kavim bir esasa rabt ve hastahanenin idaresi muktedir ve haysiyetini tanır ellere tevdi olunca o paralar, o aletler mülk ve milletin nef'ine yarar bir hale inkılâb ediyordu. Bu kere haber aldığımız ve emsali vakalar en mükemmel hastahanelerde bile muazzam telakki edilen muvaffakiyet-i cerrahiye merkez hastahanesinin halkımızı İstanbul vesair yerlere müracaata mecbur etmeyecek bir salâhı kazandığını ve binâenaleyh vilâyetin o müessese-i hayriyeye masruf-1 himematının tamamile mahalline sarf edilmekte olduğunu gösteren pek mühim bir delil olduğu için berverch-i ati tebriklerle naklediyoruz; Hastahane sertabib ve operatörü Ömer Vasfi Bey’in validesi Zekiye Hanım'ın karnında zararsız bir halde, mütemevviç, çocuk başı cesametinde bir (ur) var imiş. Dokuz seneden beri rahatsızlık vermeyen (ur) 31 Mayıs 1335 [1919] da öğle vakti birden bire büyümeğe ve gayet sancımağa başlar, hastada kay, idrar tutukluğu, peklik [kabızlık] son dereceyi bulur. Sancılar morfin şırıngalarile de teskin edilemez. Mühim ve müstacel bir vaka karşısında olduğunu anlayan Ömer Vasfi Bey’in birkaç meslekdaşile ettiği istişare-i tıbbiye (ur)'un kendi sapı üzerinde döndüğü ve "insidâd-1 ema" ya sebebiyet verdiği merkezinde takarrür ile ameliyeden evvel tecrübeten birtakım müdavat icra edilirse de otuz altı saat devam eden bu müdavattan müsmir bir netice elde edilemediği gibi hastanın ahval-i umumiyesi de cidden vehamet kesbeder. Herhalde ameliyeye lüzum görülür. Kadıncağız 2 Haziran 1335 [1919]'da alessabah hanesinden hasahaneye nakl olunarak mahdumu Ömer Vasfi Bey, emraz-1 cerrahiye-i nisa mütehassıslarından ve şehrimizdeki serbest etibbadan Kiryako Ksenidis

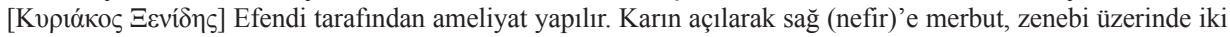
defa dönmüş, bir büyük adam başı cesametinde, muhtekin bir ur (fibrom-verem-i lifi) görülerek usul-i mahsusası veçhile istisal edilir. Çıkan ur tam dört okka gelmiştir. Hastanın yaşı altmışı geçkin, karnından çıkan sıklet dört okka olduğundan kalbî buhranat, urun tazyikile zedelenen bağırsak ve idrar yollarında ihtilatat başlamış ise de fennin en son vesaitine müracaat edilerek tehlikenin önü alınmış ve bugün ameliyatın yedinci günü olduğu halde vehamet 100'e 98 gaib olarak hastanın hayatı kazanılmıştır. Doktorumuzun validesine tam ve acil şifa temenni ederiz. Eğer hastahane 1slâh olunmamış, irfan ve fen erlerine teslim edilmemiş olsa idi mevcut müessese ve mevcut âlât hiçbir şeye yaramayacak, zavallı kadıncağız mahv olup gidecekti ve kim bilir şimdiye kadar böyle ne kadar insanlar mahv olup gitmiştir. Hastahanenin ahalinin başka yerlere arz-1 ihtiyaç ettirmeyecek bir hale ifrağı zaman-1 devletlerinde müyesser olan vali paşa [Muhittin Paşa] hazretlerinin umur-1 sıhhiyeye matuf himemat-i âsafaneleri devam ettikçe vilâyetin daha büyük icraat-1 sıhhiyeye mazhar olacağı şüphesizdir." 
beri fevkalade müteharrik [hareketli] ve sert, hacmi senebesene tedrici bir surette büyümekte olup şayan-1 dikkat bir rahatsızlık vermiyor. Muayenede rahme merbut ve tahte'l-periton bir verem-i lifi [intraperitoneal fibroma] teşhisi konuyor. Veremin batın derununda nihayet derecede taharrükiyetinden [hareketliliğinden] başka hiçbir ızdırabı hissolunmadığı için müdehale-i cerrahiyeye hasta muvafakat etmiyor. Son sene zarfında veremin hacmi ufak bir karpuz cesametini aldığından naşi mihaniki [mekanik] tesiratile bazı midevi ve meai rahatsızlıklar baş gösteriyor. Sıhhati yerinde olarak iş ve gücüyle meşgul olan hasta bir gün hane derununda eğilerek iş görmeği müteakip birden bire şedid bir veca-i batniyeden [şiddetli bir batın ağrısından] muzdariben yatağa yatmağa mecbur kaldı. Morfin zerkatına karşı bile isyan eden bu sancının intişarı amud-ı katani [lomber vertebral kolon] ve hufre-i harkafiye-i yümnaya [sağ iliak fossaya] doğru. Humma mâdum [ateş yok], muhati ve safravi kayıat [mukozik-sümüksü ve safralı kusmalar] mevcud. Sanc1 ile birlikte huruc-1 gazat ve mevadd-1 gaita kesiliyor. Veremin hacmi anbean mahsus bir surette mütezayid olduğu gibi taharrükiyeti de kesb-i mahdudiyet eylemekte [tümör büyüdüğü için hareketi de kısıtlanmakta]. Muhafazakâr tedavilerle vakit geçirdiğimiz yirmi dört saat zarfinda verem cidar-1 kuddami-i batnı [batın ön duvarını] hemen tamamen işgal eyleyecek derecede hacmen terakki eylemiş olup kar' ve cess-i batni ile ema ve ahşayı saireye dair vazıh araz almak adimü'l-imkân [batın palpasyonu ve perküsyonu ile bağırsak ve diğer iç organlara dair açık bulgu edinmek imkânsız]. Nabız ince ve mütezayid [artmış], usret-i teneffüs [nefes darlığı] fevkalade, ahval-i umumiye düşkün [genel durumu bozuk]. İdrar pek az, yirmi dört saat zarfında çıkan mikdar üçyüz gram, büyük lavmanlara rağmen mevadd-1 gaita ve gazatın hurucu mümkün olamıyor.

Tümörün zenebi [kuyruğu] üzerinde tedviri [dönmesi] ve bu tedvire emanın da biliştirak insidadı [bundan dolayı oluşan bağırsak obstrüksiyonu] ve halibin tazyike [üreterin basınca] uğrayarak kilyeler vezaifinin duçar-1 ihtilâl olması [böbreklerin fonksiyon bozukluğu] teşhis ve mütalaasile validemi ameliyat masasına yatırdım.

Feth-i batın [laparotomi] ile tümör muhtekin [hematomlu] ve fevkalade sert, nefir-i eymene [sağ tubaya] dört parmak kadar ariz ve fakat ince bir zeneble merbut görülüp soldan sağa zenebi üzerinde iki hareketle iade olundu. Verem kolon-i said [asendan kolon] ve hufre-i harkafiye-i yümna [sağ iliak fossaya] üzerine olanca sıkletile istinad etmiş olup o kısım ema fevkalade soluk bir manzara arz ediyordu. Ema zenebin bu tedvirine iştirak etmemişti. Verem istisal edilerek [tümör çıkarılarak] batın kapatıld1ktan on iki saat sonra mevadd-1 gaita ve huruc-1 gazat yine mâdum; evcâ müstesna olmak üzere ameliyeden evvelki rahatsızlıklar, fazla miktarda masl-1 sınai [serum], eter ve kokain şırıngaları gibi tıbbi imdadlara rağmen, vahim bir şekil alıyordu. Bu müddet zarfında sondajla gayet az idrar alınabildi. On ikinci saati müteakip bolca ve sık sık idrar gelmeğe, aynı zamanda kanla mülemma mevadd-1 gaita çıkmağa başladı. Yirmi dört saat sonra validemin hayatı kazanılmış idi.

Veremin sıkleti beş buçuk kilo olup muayene-i nesciyesi [histolojik muayenesi] mütekellis [kireçleşmiş] bir fibrom teşhisini teyid eyledi.

Vakamızda eğilip iş görmek harekâtile veremin zenebi üzerinde iki defa bittedvir kesb-i hacm edip kolon-i saidi ve halib-i eymeni tazyik ve insidâd-1 ema ve halibe sebeb olarak müdahale-i müstaceleyi istilzam eden bir tehlike tevlid eylediği anlaşılmaktadır. Melena kolon-i said gışâ-yı muhâtisinin tazyik neticesinde âfetzede olmasile izah olunur.

Evrâm-1 habise-i batniyede fazla taharrükiyetin bu gibi avakıbını da düşünmek mecburiyetini işbu vaka pek güzel gösterir. 


\section{Ek 3. Ömer Vasfi Aybar'ın "Sıhhiye Müdür-i Umumisi Dr. Abdullah Cevdet Beyefendi'ye Açık Mektub"u (Mefkûre sayı 4 (21 Nisan 1335 [1919]): 5-6)}

Muhterem Üstad,

Büyük bir cesaretle en mühim bir makamın bâr-1 mesuliyetini deruhde ettiniz; uzun ve tahribkâr senelerin ihmal ve imhalile tefessüh etmeğe başlayan bir anasır-1 marize iksir-i hayat bahşedecek icraat, sahib-i içtihadın sa'y ü himmetinden doğacak...

Malum-i fâzılaneleridir ki millet-i Osmaniyenin altı yüz senelik didinmesinden iyi netice çıkmaması verilecek kararlarda gösterilen azîm tereddütlerle, verilen kararları tatbik ve icra hususundaki noksan-i azm ve himmetten münbaisdir. Hükûmet-i Osmaniye'nin Sultan Selim-i Salis devrinden itibaren vakit vakit teceddüd ve terakki uğrunda, velev birçok tereddütlerden sonra olsun, ne kadar musib [isabetli] kararlar verdiği ve fakat aynı zamanda işe başlanılmamasını müteakip ihmal edilerek mahv ve akim kalmış oldukları müberhen [ispatlanmış] bir hakikattir. Darülfünun şimdiki Adliye Nezareti binasında ilk küşad olunduğu zaman celbedilen âlât ve edevat ve vesait-i fenniyenin Avrupa'dakilere rekabet edecek bir derecede olduğunu ve bunu ihzara müteallik [hazırlamaya yönelik] mesainin ne kadar ciddi tutulduğunu Reşid Paşa'nın vesaik-i siyasiyesi meyanında görmüştüm. Eğer o zaman başlanan iş takip olunsaydı bugün Atina Darülfünunu'na gıpta edecek bir mevki-i pestide [alçak mevkide] bulunmazdık; bunu bir misal olarak getirdim. Tarih-i Osmaniyenin son asrı zarfında başka cihetlerden birçok misaller de bulunabilir.

Memleketin sıhhi ihtiyacatını düşünmek meselesine gelince: Maalesef bu mesele henüz devr-i tereddüt geçirmektedir. Memlekette sıhhi icraata ne yolda başlanılmak lâzım geleceği hall olunmamıştır.

Altı yüz senelik bir devlet, payitahtında bile mükemmel bir hastahaneye malik değildir! Erbab-1 ihtisasımız ve oldukça paramız var iken meydanda yine bir şeyler olmamasının sebebi bendenizce pek aşikârdır: Sıhhi emel ve faaliyetler bir noktada temerküz etmemiş, ne yapılmak lâzım geleceği tesbit ve takrir olunmamış... Memleketimizde ne kadar müessesat-1 sıhhiye var ise o kadar da karışık merciler var, fen noktasında tecemmu eden etibba icraat hususunda muhtelif nukat-1 nazar yürüten muhtelif makamların esiri!

Üstad, ilk beyanatınızla meseleye can damarından temas ettiniz: Faaliyet-i shhiyenin tevhidi ve makam-1 alinizin istiklâli... Evet, yalnız bu iki esası kaviyyen tesbit ederseniz tarih nazarında zaten bülend olan namınız daha ziyade yükselecektir. Bize sahib-i fazl olmakla beraber sahib-i içtihad ve azm adamlar lâzımdır.

Sefalet ve harabi içinde yüzen şu zavallı vatanı diriltecek isek bu sa'y-i bi-nihaye de en ziyade iş görecek sınıf, etıbbadır. Sulhden sonra düşkün bir unsurun zûr-1 bâzû-yı marizanesinden [hastalıklı kollarından] başka bir sermaye-i tealimiz yoktur. Hükûmetin varlığı ancak unsur-i mariz ve sefili ihyâ ile kaimdir. Silsile-i icraatımızın birinci maddesi sıhhat-i umumiyeyi muhafaza uğrunda mücadele olmalıdır. $\mathrm{Bu}$ mücadeleye hayatile iştirak edecek olan etibbanın faaliyetini müsmir kılacak teşkilat lâzımdır. Yeni ihtiyaçlar, yeni fikirler ister. Bu hususta terahi ve tekâsül [gevşeklik] kat'iyyen caiz değildir.

Faaliyet-i sıhhiyenin tevhidi ve makam-1 ali-i sıhhinin istiklâli... Bu beş-altı kelime büyük bir programın ifadesidir.

Üstad, İsviçre'de, Mısır'da, İstanbul'da harpten ve hürriyetten evvel ve sonra metîn bir içtihad ve sarsılmaz bir metanet sahibi olduğunuzu yazılarınız ve muazzam bir eser-i himmet olan kitabhanenizle maddeten isbat etmiş bir fâzılsınız. Senelerce zulm veçhile, taassub ve gaflete karşı muzafferane mücahede ettiniz. Ye's ve hırmana [ümitsizliğe ve mahrumiyete] düştügümüz zamanlar, 
Aş̧inâyız, bize bîgânedir endişe-i mevt,

Âdl ü hak uğruna nezreylemişiz cânımızı

gibi cür'et ve cesaret telkin eden yazılarınızla yeniden yeniye kesb-i gayret ederdik. Her şeyden evvel bütün beşeriyet için sızlayan bir kalbe maliksiniz. Millet Çanakkale Harbi'nin zafer teranelerile cûş u hurûşa getirilirken siz bütün âlem-i medeniyete karşı,

Yoğur gözyaşııla humk ve gufrânı

Savur çehre-i rahmine "Dardanel"

Duyuları ăglatan, bu kahr-ı âbadı

Asirlara göster, sen ey kandan el

feryadında bulunuyordunuz. Hâsılı, "Vatan bizlere ne Türkiye'dir, ne Türkistan..” saçmalarına karşı kemâl-i cesaretle; Vatan bize ebedi ve mukaddes bir ülkedir: Irfan! diye bağırarak Türkleri, Türkçülerin şerrinden kurtarmağa çalışıyordunuz.

Üstad, bütün bu mücahedatın zavallı millete bir nefha-i hayat bahşedecek icraat-1 słhhiyenle tetevvüç edecektir. Sen ki derdi ilk gününde teşhis ettin, azm ve içtihadınla elbette zaferyâb olursun... Bâkî dü dost fâzılanelerini takbil ile teveccühat-1 pederanelerinin bekası ehass-1 âmâlimdir efendim. Ömer Vasfi.

\section{Kitap ve risaleler}

\section{Ek 4. Dr. Ömer Vasfi Aybar’ın Yayınları ${ }^{43}$}

1- Seyyar Hastahanelerde Hidemat-ı Cerrahiye. Diyarbakır: Dicle Matbaası, 25 Nisan 1334 (25 Nisan 1918) ["Birinci Cihan Harbi'nin sonlarına doğru basılan bu risale, ordu seyyar hastanelerinin kitap kadrosuna ilave edilmiştir"].

2- Başlıca Kanserlerin Teşhisi. Prof. Hartman'dan çevirenler Kâzım İsmail Gürkan ve Ömer Vasfi Aybar. İstanbul: İlhami-Fevzi Matbaas1, 1928.

3- İkinci Türk Cerrahi Kongresine Rapor: Umumi İptal-i His Hakkında. İstanbul: Kader Matbaası, 1933.

4- İstanbul Çocuk Hastanesi Tarihine Dair. İstanbul: Sağlık ve Sosyal Yardım Bakanlığı Yayınları, 1948.

\section{Eski harfli makale, müşahede, etüt ve çevirilerinden bazıları}

1- "Küsur-1 muhtelite-i müntinenin tedavisi," Ceride-i Tibbiye-i Askeriye 46, 6 (Temmuz 1333 [1917]): 93-97. (Diyarbakır Hastahanesi Operatörü Mükellef Yüzbaşı Ömer Vasfi).

2- "Seyyar hastahanelerde hidemat-1 cerrahiye [1]," Ceride-i Tibbiye-i Askeriye 47, 19 (Ağustos 1334 [1918]): 507-514 [Diyarbakır Emraz-1 Hariciye Hastahaneleri Operatörü İhtiyat Yüzbaşı Ömer Vasfi] [Daha önce Diyarbakır'da risale olarak neşredilen eser].

3- "Seyyar hastahanelerde hidemat-1 cerrahiye [2]," Ceride-i Tibbiye-i Askeriye 47, 20 (Eylül 1334

[1918]): 545. [Daha önce Diyarbakır'da risale olarak neşredilen eser].

4- “Acilen müdahaleyi müstelzim bir verem-i batnî vakas1," Darülfünun Tıb Fakültesi Mecmuası 2, 2 (Teşrinievvel 1335 [1919]): 88-90. (Ankara Hastahanesi Sertabibi Op. Dr. Ömer Vasfi). Ömer Vasfi Bey'in kendi annesine uyguladığı ameliyatın olgu sunumudur. Bu yazının çeviriyazısı için bkz. Ek 2.

5- "Cürûh-1 nâfize-i batniyyede müdahale mes'elesi," Türk Hekimi sayı 1 (1 Mart 1336 / 1 Mart 1920): 2-3.

6- "Frengiye dair tıbbi nasihatler," Türk Hekimi say1 2 (26 Nisan 1336 / 26 Nisan 1920): 4-5.

43 Yayın listesinin bir kısmında aşağıdaki kaynaklardan istifade edilmiştir: Nimet Taşkıran, Süreli Türk Tip Yayınlarında Cerrahi Makaleler Bibliyografyası (İstanbul: Zeynep-Kâmil Ana ve Çocuk Sağlığını Koruma Derneği, 1968); Sait Naderi ve Gülten Dinç, "Darülfünun Tip Fakültesi Mecmuası (1916-1933) ve Dizini," Tip Tarihi Araştırmaları sayı 12 (2004): 200-253; İbrahim Yıldırım, Hakan Ertin ve İbrahim Başağaoğlu, "Türk Tip Tarihinde “Anadolu Kliniği” (1933-1954),” Anatolian Clinic 21, 1 (January 2016): 4-41. 
7- "Dâhil-i rahim-i key’at [İnrauterin koterizasyonlar]" Türk Hekimi say1 2 (26 Nisan 1336 / 26 Nisan 1920): 7-8. Le Monde médical'den çeviri.

8- "Batına doğum hakkında iki müşahede," Anadolu Tıb Mecmuası 1, 3 (15 Şubat 1338): 24-25. (Giresun Memleket Hastahanesi Sertabib ve Operatörü Dr. Ömer Vasfi).

9- "Müstacel cerrahi mebahisinden: İleuslar [1]," Anadolu Tıb Mecmuası 1, 8 (15 Temmuz 1338): 5-7. (Ankara Mülkiye Hastahanesi Sertabibi Op. Dr. Ömer Vasfi).

10- "Müstacel cerrahi mebahisinden: İleuslar [2]," Anadolu Tıb Mecmuası 1, 9 (15 Eylül 1338 / 15 Eylül 1922): 8-12. (Ankara Mülkiye Hastahanesi Sertabibi Op. Dr. Ömer Vasfi).

11- "Nâdirü'l-emsâl bir vak'a-i cerrahiye (28.7.1338)," Anadolu Tıb Mecmuası 1, 9 (15 Eylül 1338): 12-14.

12- “Anevrizmaların cerrahi tedavisine dair," Askeri Tıb Mecmuası 52, 10-11-12 (Teşrinievvel-TeşrinisaniKanunuevvel 1339 /1923): 331-334 (Ankara Mülkiye Hastahanesi Sertabibi Op. Dr. Ömer Vasfi).

13- "Rahim fibromiyomlarının tedavisi: Hangi vakalar ameliyeye ve hangi vakalar tedavi-i şuaiyeye gönderilecek?," İstanbul Seririyatı 6, 1 (4. cild, say1 7) (Mayıs 1340 / May1s 1924): 599-603 (Ankara Vilayet Hastahanesi Sertabib ve Operatörü Ömer Vasfi).

14- "İnsülin ile şekerli diyabet tedavisi," Hastahane 1, 1 (Teşrinievvel 1340 / Ekim 1924): 7-9.

15- "Mide ve mea-i isnaaşer afat-1 cerrahisi [1]," Hastahane 1, 2 (Teşrinisani 1340 / Kasım 1924): 1-3.

16- "Humma-yı nifasi tedavisine dair," Hastahane 1, 2 (Teşrinisani 1340 / Kasım 1924): 11-13.

17- "Haml ez-haric-i rahmin esbab ve tedavisine dair," Hastahane 1, 3 (Kanunuevvel 1340 / Aralık 1924): 24 (Zentralblatt für Gynäkologie, V. Oettingen'den özet").

18- "Mide ve mea-i isnaaşer afat-1 cerrahisi [2]," Hastahane 1, 4 (Kanunusani 1341 / Ocak 1925): 9-13.

19- "Cism-i asferin [corpus luteum] temezzukundan mütevellid nezf-i batni," Hastahane 1, 5 (Şubat 1341 / Şubat 1925): 16 (Annals of Surgery’den çeviri).

20- "Ameliyat esnasında evramın teşhis-i hurdebinisi," Hastahane 1, 7 (Nisan 1341 / Nisan 1925): 16.

21- "Telsiz telgrafla tıbbi muayenat," Hastahane 1, 8 (May1s 1341 / May1s 1925): 16 (Gazette des Hôpitaux'dan çeviri).

22- "Somnifen ile ibtal-i his," Hastahane 1, 8 (May1s 1341 / Mayıs 1925): 16 (Gazette des Hôpitaux'dan çeviri).

23- "Tecrübevi Hyperpnée ile sar'a-i jaksoni," Hastahane 1, 8 (May1s 1341 / May1s 1925): 16 (Gazette des Hôpitaux'dan çeviri).

24- "Mide ve mea-i isnaaşer afat-1 cerrahisi [3]," Hastahane 1, 9 (Haziran 1341 / Haziran 1925): 13-15.

25- "Mide ve mea-i isnaaşer afat-1 cerrahisi [4]," Hastahane 1, 11 (Ağustos 1341/ Ağustos 1925): 11-15.

26- "Gonokoklu iltihab-1 mecra-yı bevlin aşı ile tedavisi," Hastahane 1, 11 (Ağustos 1341 / Ağustos 1925): 16 (Gazette des Hôpitaux'dan çeviri).

27- "Extrait hypophysaire veyahud pituitrine," Hastahane 2, 13 (Teşrinievvel 1341 / Ekim 1925): 15-16.

28- "Mide ve mea-i isnaaşer afat-1 cerrahisi [5]," Hastahane 2, 13 (Teşrinievvel 1341 / Ekim 1925): 1-3.

29- "Sünnet meselesi," Hastahane 2, 13 (Teşrinievvel 1341 / Ekim 1925): 14-15.

30- "Cevf-i rahmin muayene-i radyolojisi," Hastahane 2, 14 (Teşrinisani 1341 / Kasım 1925): 1-4 (Revue de Chirurgie'den çeviri).

31- "Telsiz Telgrafla Muayene-i Tibbiye," Íctihad 20, 182 (15 Haziran 1925): 3628-3629 (Gazette des Hôpitaux'dan çeviri).

32- "Menşei travmatik olarak mayi-i damaği-i şevkinin "Had tenezzül-i tevettür”̈̈," Hastahane 2, 17 (Şubat 1926): 1-5 (Revue de Chirurgie'den çeviri).

33-“Seretanın seyr-i tekâmülünde kan formülünün tahavvülat1," Hastahane 2, 17 (Şubat 1926): 1516 (Journal de Chirurgie' den çeviri).

34- "Anatoksin ile difteri muafiyet-i faaliyesinin davamına dair," Hastahane 2, 18 (Mart 1926): ön kapak arkasında (Presse médicale'den çeviri).

35- "Anatoksin ile tetanoz muafiyeti," Hastahane 2, 18 (Mart 1926): 1-4 (Presse médicale'den, Dr. Mecid ile birlikte çeviri).

36- "Altı muhitî tederrün vakasında muhit-i şiryanı kat'-1 asab-1 simpatinin verdiği netâyic," 
Hastahane 2, 20-21 (May1s ve Haziran 1926): 1-5 (Revue de Chirurgie'den çeviri).

37- "Harb cerrahisi hasebile hiyate-i ibtidaiye ile tedavi edilmiş 72 trepanasyon ameliyesi 19141915," Hastahane 2, 21-22 (Mayıs ve Haziran 1926): 17-19 [Say1 numaras1 22-23 olmas1 gerekirken 21-22 olarak yanlış verilmiş̧ir].

38- "Cüruh-1 şiryaniyenin harici enzife-i şedidesinden mütevellid had aneminin tedavisi ve nefsüddem," Hastahane 3, 27 (Mart 1928): 10-15 (çeviri).

39- "Seretana aid müşahedeler," Hastahane 3, 29-30 (May1s ve Haziran 1928): 20-21. (Journal de Chirurgie'den çeviri).

40- "Dil seretanının teşhisi," Hastahane 3, 29-30 (Mayıs ve Haziran 1928): 22-23 (çeviri).

\section{Yeni harfli makale, müşahede, etüt ve çevirilerinden bazıları}

1- "Kranioplasti istitbab ve tasni usulleri," Sihhiye Mecmuast 5, 29 (Ağustos 1929): 940-960.

2- "Delinme peritonitleri," Sihhiye Mecmuast 5, 33 (Kanunuevvel 1929): 1553-1565.

3- "Sinir dikilmesi ve tam muvaffakiyet gösteren bir müşâhede," Hastahane 5, 2 (1930): 22 (Dr. Şükrü Yusuf Sarıbaş ile birlikte).

4- "Un cas d'ulcère du pylore perforée avec persistance de la permabilité pylorique [Pilor permabilitesinin devamı ile birlikte delinmiş bir pilor ülseri vakas1]," Ankara Kliniği 1, 1 (1930): 22-24.

5- "Ayak parmaklarının gangreni vakasında sempatektomi arteriel hakkında bir müşahede," Ankara Kliniği 1, 2 (1930): 37-38.

6- "Biri cerrahi tedavi ile diğeri kendiliğinden iyi olmuş iki akciğer kist idatiği," Ankara Kliniği 2, 7 (1932): 130-138.

7- "Umumi iptali his hakkında," Ankara Kliniği 4, 5-6 (1933): 87-94.

8- "Sağ kilye kutbu ulvisindeki bir taşın nadir görülen ihtilâtatından tali plevra ampiyemi ve transplöral taşın ihracı," Ankara Kliniği 5, 3 (1934): 2-3.

9- "İnşak ile elde edilen umumî iptal-i histe umumî prensipler ve bir Muptilihis intihabı meselesi" Anadolu kliniği 2, 2 (Eylül 1934): 68-69.

10- "Fekki ulvi sarkomu," Türk Tip Cemiyeti Mecmuası 4, 1 (1938): 7.

11- "Kraniyoplasti hakkında," Anadolu Kliniği 6, 3 (Temmuz 1938): 105-107.

12- "Bir choledoque darlığı vak'as1," Poliklinik sayı 103 (1942): 95-99.

13- "Hemorroide'lerin cerrahî tedavisi," Anadolu Kliniği 11, 1 (Mayıs 1944): 30-31.

14- "Yine hemoroitlerin cerrahî tedavisi hakkında," Anadolu Kliniği 13, 1 (May1s 1946): 34-38.

15- "Askaritlerin sebep olduğu bir insidat vakas1," Şirurji 1, 1 (1947): 104-106.

16- "Kemital sodium kullanarak vena yolu ile yapılan jeneral anestezi," Şirurji 2, 1 (1948): 40-45.

17- "Bir çene ankilozu," Şirurji 1, 4 (1948): 191-195.

18- "Hepatoco-gasrostomi vakas1," Şirurji 2, 4 (1949): 184.

19- "Egü [akut] apandisit arazı ile kendini gösteren bir plazmositom vakası," Şirurji 3, 3 (1949): 83-88. 20- "Aiguë appendicite arazı ile kendini gösteren bir extramedulla," Hastane 6, 3 (1952): 70-75.

\section{Paramedikal yayınları}

1- "Harbden sonra: Tenakus-1 nüfus meselesi: Anasır-1 saireye nisbetle Türk'ün zayiat1... Etibbamızı bilfiil hizmete davet," İkdam Gazetesi,14 Kanunuevvel 1334 (14 Aral1k 1918), No. 7845, s.1-2.

2- "Hükûmet ve etıbba," Mefkûre say1 2 (7 Nisan 1335 / 1919): 4-5. [Yerel yönetim kadrolarıla etibba arasında hıfzıssıhha işlerinin çözülemeyeceği bir şekilde ast-üst ilişkisi bulunması dolayısıyla hekimlerin yetkilerinin arttırılması gerektiğine dair yazı].

3- "Sihhiye Nezareti," Mefkûre say1 3 (14 Nisan 1335 / 1919): 3-4. [Umur-1 sihhiyenin müstakil bir nezaret altında ve daha programlı bir şekilde yürütülmesi gerektiğine dair fikirlerini içeren yazı].

4- "Sıhhiye Müdür-i Umumisi Dr. Abdullah Cevdet Beyefendiye Açık Mektup," Mefkûre say1 4 (21 Nisan 1335 / 1919): 5-6.

5- "Acı da olsa doğru," Mefkûre sayı 7 (16 Haziran 1335 /1919): 2-3. [Taşra sıhhiye hizmetlerinin çok geri olmasından dolayı mecburi hizmetin getirilmesi ve taşrada hekim istihdamı ile ilgili yazı]. 
6- "Tehlikenin dehşeti karşısında," Mefkûre say1 9 (28 Haziran 1335 / 1919): 1-2. [Frengi meselesinde tehlikenin büyüklüğü ve gösterilen lakaytlığı eleştiren yazı].

7- "Maksad hayata hizmet ise," Mefkûre say1 12 (21 Temmuz 1335 / 1919): 1-2. [Frengi meselesine dair meseleyi islam kadınları üzerinden dini bir tartışma açan Sebilürreşad muharrirlerine Ömer Vasfi Bey'in verdiği sert cevap].

8- "Harb-i umumide memleketimizde faaliyet-i cerrahiye," Türk Hekimi say1 2 (26 Nisan 1336 / 26 Nisan 1920): 1-3.

9- "Cerrahi tarihine ait tedkikler: Ezmine-i kable't-tarihiyyede ve akvam-1 ibtidaiyyede tatbikat-1 cerrahiye," Hastahane 1, 8 (Mayıs 1341 / 1925): 11-15.

10- "Bir şaheser-i tıbbi," Hastahane 2, 13 (Teşrinievvel 1341 / Ekim 1925): 16. [Sıhhiye ve Muavenet İçtimaye Vekâletince basılan "Sıhhat-i Umumiye İdaresi Esasatı" eserinin tanıtımı].

11- "Çanakkale savaşlarında Maydos bombardımanı," Hayat Tarih Mecmuası 1, 2 (Mart 1967): 19-23.

12- "Türk Cerrahi Cemiyetinin tarihçesi," Şirürji 1, 1 (1947): 40-48.

13- "Hastanenin Kısa Tarihçesi (Ankara Numune Hastanesi)," Ankara Numune Hastanesi Bülteni 1, 1 (1961): 5-11.

\section{KAYNAKÇA / BIBLIOGRAPHY}

\section{Basılı Kaynaklar / Printed Sources \\ Dergi ve Gazeteler / Periodicals and Newspapers}

Anadolu Tıb Mecmuası 1, 9 (15 Eylül 1338 / 1922); 1, 5 (15 Nisan 1338 / 1922); 1, 8 (15 Temmuz 1338 / 1922). Askeri Tıb Mecmuası 1, 1 (Kanunuevvel 1337 / 1921); 52, 10-11 (Teşrinievvel - Teşrinisani - Kanunuevvel

1339 / 1923); 56, 11 (Teşrinisani 1927).

Ayln Tarihi 25, 84-85 (Mart - Nisan 1931).

Darülfünun Tıb Fakültesi Mecmuası 2, 2 (Teşrinievvel 1335 / 1919).

Doktor Mecmuast say1 3 (1 Nisan 1336 / 1920).

Hastahane 1, 1 (Teşrinievvel 1340 / 1924); 1, 2 (Teşrinisani 1340 / 1924); 1, 3 (Kanunuevvel 1340 / 1924);

1, 4 (Kânunusani 1341 / 1925); 1, 5 (Şubat 1341 / 1925); 1, 9 (Haziran 1341 / 1925); 1, 11 (Ağustos 1341 / 1925); 1, 12 (Eylül 1341 / 1925); 2, 13 (Teşrinievvel 1341 / 1925); 2, 14 (Teşrinisani 1341 / 1925); 2, 18 (Mart 1926); 2, 20-21 (Mayıs ve Haziran 1926); 2, 23-24 (Eylül ve Teşrinievvel 1926); 3, 25 (Teşrinievvel 1927); 3, 29-30 (Mayıs ve Haziran 1928); 3, 31 (Temmuz 1928).

İctihad 20, 182 (15 Haziran 1925).

İkdam No. 7845, 14 Kanunuevvel 1334 (14 Aralık 1918).

İstanbul Klinik Dersleri 2, 7 (Ekim 1949).

İstanbul Seririyatı 5, 11 (Mart 1340 / 1924); 3, 9 (Kanunusani 1339 / 1923); 3, 13 (Mayıs 1339 / 1923).

Mefkûre say1 2 (7 Nisan 1335 /1919); say1 3 (14 Nisan 1335 /1919); say1 4 (21 Nisan 1335 / 1919); say1 6 (9 Haziran 1335 /1919); sayı 7 (16 Haziran 1335 /1919); say1 9 (28 Haziran 1335 / 1919); say1 12 (21 Temmuz 1335 / 1919).

Milliyet Gazetesi, 27 Ağustos Çarşamba 1969.

Sihhiye Mecmuası 5, 22 (Kânunusani 1929); 13, 86 (Haziran 1937).

Türk Hekimi numero 1 (1 Mart 1336 / 1920); numero 2 (26 Nisan 1336 / 1920). 


\section{Kitap ve Makaleler / Books and Articles}

Altay, Sadet. Atatürk Döneminde Numune Hastanelerine Dönüstürülen Osmanlı Hastaneleri (1924-1938).

Ankara: Atatürk Araştırma Merkezi, 2019.

Aybar, Ömer Vasfi. “Çanakkale Savaşlarında Maydos Bombardımanı.” Hayat Tarih Mecmuası 1, 2 (1967): 19-23.

Aydoğan, Erdal, ve Şaban Ortak. Dr. İbrahim Tali Bey’in Günlüğü. İstanbul: Arba, 2000.

Başağaoğlu, İbrahim, ve Eren Akçiçek. "Atatürk'ün Yurt Seyahatlerinde Ziyaret Ettiği Sağlık Kurumları." Atatürk Dönemi Sağllk Tarihi Kongresi (1920-1938) Bildiriler içinde 771-786. İzmir: Ege Üniversitesi Basımevi, 2009.

Birinci, Ali. “Türk Yurdu kalemleri: Dr. Muhittin Celal Duru.” Türk Yurdu 352 (2016): 64-69.

Cumhuriyetimizin 75. Yllında Ankara Numune Eğitim ve Araşstırma Hastanesi. Ankara: Ankara Numune Eğitim ve Araştırma Hastanesi, 1998.

Erden, Fethi. Türk Hekimleri Biyografisi. İstanbul: Çituri Biraderler Basımevi, 1948.

Erduran, Behçet Sabit. Cephedeki bir Doktorun Gözünden: 1915 Baharında Çanakkale. Yayına hazırlayan Tamay Açıkel. İstanbul: Türkiye İş Bankası Kültür Yayınları, 2015.

Etker, Şeref. “Ophtalmoscope Essad.” Osmanlı Bilimi Araştırmaları 9, 1 (2008): 151-164.

Naderi, Sait, ve Gülten Dinç. "Darülfünun Tıp Fakültesi Mecmuası (1916-1933) ve Dizini.” Tip Tarihi Araştırmaları say1 12 (2004): 200-253.

Neşet Osman [Usman] ve Mehmed Kemal [Öke]. Cerrahi-i Harbiyeye dair Malumat ve Müşahedat. 18 Nisan'dan 30 Ağustos 1331'e Kadar Hastahaneye Duhul Eden Mecruhin Üzerinde Yapllan Tedkikat ve Tedavi ile Bazı Nadir ve Müfid Vekayi. Yayına hazırlayanlar Yetkin İşçen ve Necmettin Özçelik. İstanbul: Gümüşsuyu Hastanesi, 2012.

Kazancıgil, Aykut. "Mısır’da Âşinâ Bir Çehre.” Derin Tarih 81 (Aralık 2018): 62-63.

Özarslan, Metin. “İşbirlikçiliğe İsyan Telgrafı Çeken Ankara: "Senin Gibi sadrazamı tanımayız." Cumhuriyet, 29 Ekim 2012.

Şehsuvaroğlu, Bedi Nuri. “Türkiye'de Sağlıkla İlgili Olarak Yayınlanan Periyodikler.” Istanbul Tip Fakültesi Mecmuası 36, 1 (1973): 169-198.

Şehsuvaroğlu, Bedi Nuri. “Basın Tarihimize Sihhi Mevkuteler.” Yeni Tip Âlemi 10 (1961): 484-501.

Şehsuvaroğlu, Bedi Nuri. Atatürk'ün Sağllk Hayatı. İstanbul: Hür, 1981.

Tansel, Selahattin. Mondros 'tan Mudanya'ya Kadar, c. 2. Ankara: Başbakanlık Basımevi, 1973.

Taşkıran, Nimet. Süreli Türk Tip Yayınlarında Cerrahi Makaleler Bibliyografyası. İstanbul: Zeynep-Kâmil Ana ve Çocuk Sağlığını Koruma Derneği, 1968.

Topuzlu, Cemil. İstibdat-Meşrutiyet-Cumhuriyet Devirlerinde, 80 Ylllık Hatıralarım. 6. bs. Yayına hazırlayanlar Hüsrev Hatemi ve Aykut Kazancıgil. İstanbul: İşaret, 2017.

Tunaya, Tarık Zafer. Türkiye'de Siyasal Partiler, Mütareke Dönemi, c. 2. İstanbul: Hürriyet Vakfi, 1986.

Unat, Ekrem Kadri. “Türk Tıp Tarih Kurumu'nun İlk Elli Yılının Tarihçesi.” II. Türk Tip Tarihi Kongresi İstanbul, 20-21 Eylül 1990, Kongreye Sunulan Bildiriler içinde 9, 12. Ankara: Türk Tarih Kurumu 1999.

Yıldırım, İbrahim, Hakan Ertin ve İbrahim Başağaoğlu. "Türk Tıp Tarihinde “Anadolu Kliniği”” (19331954).” Anatolian Clinic January 21, 1 (2016): 4-41.

Yıldırım, Nuran. "Hekim Kimliği ile Abdülhak Adnan Adıvar ve Tıp Tarihi ve Deontoloji Müderrisliği." Osmanlı Bilimi Araştırmaları 7, 2 (2006): 55-86. 
Wieting, Julius. Rehber-i Cerrahi-i Harbi. Gülhane Seririyat Külliyat Mesaisi 18. İstanbul: Ahmed İhsan ve Şürekâsı Matbaacılık, 1330 (1914).

Wieting, Julius. Cürûh-ı Harbiyeden Mütevellid Tagayyürat-ı Vazifeviyenin Tedavi-i Muahharası Hakkinda Rehber. Gülhane Seririyat Külliyat Mesaisi 19. İstanbul: Ahmed İhsan ve Şürekâsı Matbaacılık, 1330 (1915).

40. Yıl Münasebetiyle Ankara Numune Hastanesi. Ankara: Ankara Numune Hastanesi, 1965.

\section{Elektronik Kaynaklar / Electronic Sources}

“Dr. Ömer Vasfi Aybar (1919-1921) (1922-1933).” Erişim 12 Mayis 2019. https://numuneeah.saglik.gov.tr/ TR,201718/dr-omer-vasfi-aybar-1919---1921-1922---1933.html 